IZA DP No. 4740

Policies to Promote Growth and Economic Efficiency in Mexico

Javier Arias

Oliver Azuara

Pedro Bernal

February 2010
James J. Heckman

Cajeme Villarreal 


\title{
Policies to Promote Growth and Economic Efficiency in Mexico
}

\author{
Javier Arias \\ University of Chicago \\ Oliver Azuara \\ University of Chicago \\ Pedro Bernal \\ University of Chicago
}

James J. Heckman

University of Chicago, American Bar Foundation

and IZA

\section{Cajeme Villarreal}

University of Chicago

\section{Discussion Paper No. 4740 \\ February 2010}

IZA

P.O. Box 7240

53072 Bonn

Germany

Phone: $+49-228-3894-0$

Fax: +49-228-3894-180

E-mail: iza@iza.org

\begin{abstract}
Any opinions expressed here are those of the author(s) and not those of IZA. Research published in this series may include views on policy, but the institute itself takes no institutional policy positions.

The Institute for the Study of Labor (IZA) in Bonn is a local and virtual international research center and a place of communication between science, politics and business. IZA is an independent nonprofit organization supported by Deutsche Post Foundation. The center is associated with the University of Bonn and offers a stimulating research environment through its international network, workshops and conferences, data service, project support, research visits and doctoral program. IZA engages in (i) original and internationally competitive research in all fields of labor economics, (ii) development of policy concepts, and (iii) dissemination of research results and concepts to the interested public.
\end{abstract}

IZA Discussion Papers often represent preliminary work and are circulated to encourage discussion. Citation of such a paper should account for its provisional character. A revised version may be available directly from the author. 
IZA Discussion Paper No. 4740

February 2010

\section{ABSTRACT}

\section{Policies to Promote Growth and Economic Efficiency in Mexico*}

This paper discusses the problems facing the Mexican economy. It operates under a heavy burden of monopoly and regulation. We focus on two issues that should receive more attention in discussions of Mexican policy. (1) The family is under stress in Mexico and this retards the growth of skills of workforce. (2) The informal sector is large, mostly due to the heavy burden of monopoly and regulation. We find little evidence that the introduction of social protection programs for workers outside the formal sector have promoted the growth of the informal sector.

JEL Classification: J13, L51, O17

Keywords: Mexico, family policy, informality, regulation

Corresponding author:

James J. Heckman

Department of Economics

University of Chicago

1126 E. 59th Street

Chicago, IL 60637

USA

E-mail: jjh@uchicago.edu

* We thank the American Bar Foundation for their sponsorship of this research. 


\section{Table of Contents}

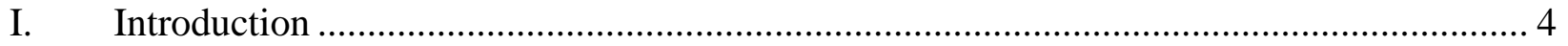

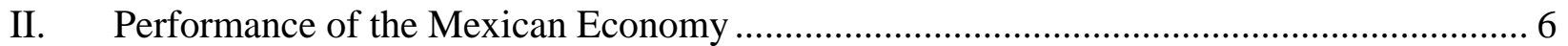

III. The Mexican Economy is Highly Regulated ………............................................................ 9

IV. Lack of Competition and Weak Infrastructure ................................................................... 12

V. Understanding the Stagnation of Work Force Productivity ………...................................... 14

A. Lack of Attention to Early Childhood Education............................................................. 17

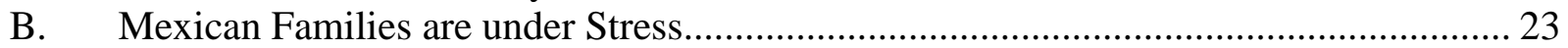

VI. The Informal Sector: Its Origins and Its Consequences.......................................................... 29

A. A Model of Self-Selection Without Investment.............................................................. 31

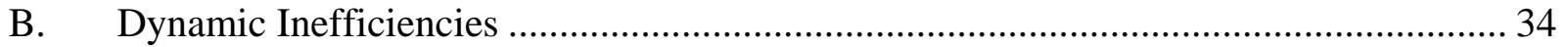

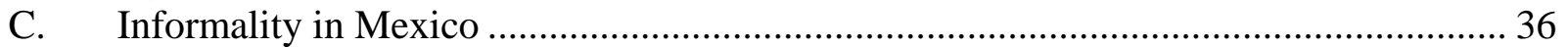

D. Seguro Popular and the Growth of Informality............................................................. 41

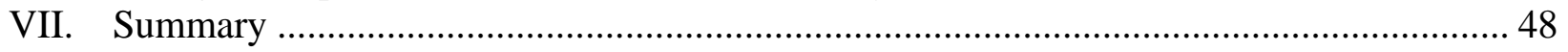

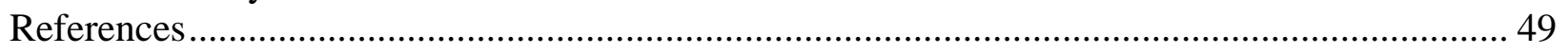




\section{Introduction}

The Mexican economy is sluggish. Some of the reasons for its poor performance are wellknown: oil revenues are down, many public institutions are weak and the level of infrastructure is low. In addition, Mexico operates under a heavy burden of regulation and monopoly that discourages investment, innovation and growth. ${ }^{2}$ These factors inhibit investment in industry, infrastructure and people, and retard economic prosperity and growth. This paper reviews these well-known causes of Mexican economic stagnation, but focuses its attention on two additional factors that should receive more attention.

The Mexican family is under stress. The proportion of children living in single parent families is increasing. For a number of reasons, these families invest less in their children. This trend slows down the growth of skills in Mexico. Family policy is one aspect of a successful growth policy.

We also examine the origins and consequences of Mexico's large informal labor market. Informality is associated with lower productivity, diminished investment and a weak fiscal base to support public investment. At issue is why the informal sector is large and what should be done about it.

Some analysts attribute the growth of components of the informal sector to an expansion of social benefits to persons excluded from the formal sector. In our view, this factor is relatively minor. Informality is a response to a flawed regulatory system. The major reason for the size of the informal sector is taxation, regulation, and rigidity. To reduce informality, Mexico has to reform the tax and regulatory system that stifles its economy.

Two powerful forces operate in economies around the world. First, the technology of production has changed and continues to change. It increasingly requires skilled labor. An economy with a skilled workforce can more easily adapt to the pace of technological change. Second, the world economy has opened up and Mexico is an active participant in it. For Mexico to compete against lower wage countries like China and Vietnam, it has to boost the productivity of its workplaces through investments in people and improvements in its tax and regulatory environment.

\footnotetext{
${ }^{2}$ A recent paper by Chiquar and Ramos-Francia [2009], completed after this work was presented, complements the analysis of this paper by also dealing with aspects of monopoly and rigidity in the Mexican economy. The OECD reports on Mexico also make these points.
} 
Successful modern economies are characterized by diversity, heterogeneity, and the pursuit of comparative advantage. They allow individuals and firms to pursue favorable trading possibilities. Institutions that were once functional in organizing society are no longer appropriate in a world of diversity and heterogeneity. Institutions that induce efficient responses to unique situations and unique people produce the greatest value in the new economy.

Rigidities of markets and excessive regulation produce static and dynamic inefficiencies that inhibit growth. When local legal frameworks obligate mandated uniformity, distinctive opportunities produced by the modern economy are suppressed. Legal frameworks that impose regulation and rigidity destroy the incentive of participants in unique employment and production decisions to foster and use their knowledge.

Built into its political culture, Mexico has a fear and even loathing of incentives and markets. It has created a legal and cultural edifice that restricts its ability to adapt to the new economy. The anti-market bias in the Mexican labor market and the economic culture of the country is embodied in two laws that date to the 1917 constitution. As an example, article 123 of the Mexican Constitution says:

"Every person has the right to a dignifying and socially useful job; for that purpose, the creation of jobs and the social organization of labor will be promoted, in agreement with the Law."

Article 3 of the Federal Labor Law, which regulates issues regarding hiring, firing, unions, etcetera, states:

"The labor is a right and social duty. It is not an item subject to trade, it demands respect to the liberties and dignity of whomever offers it, and it must be carried out in conditions that ensure the life, health and a decent economic level for the worker and their family."

The ethos of these and other laws permeate Mexican economic life. As a result, Mexico operates under a heavy burden of rigid local laws and social institutions. Key economic sectors are either monopolies or virtual monopolies. Innovators are effectively prevented from entering and improving many sectors. For example, there is a significant concentration of market power in important product markets such as energy (oil and electricity), telecommunications, media and

\footnotetext{
${ }^{3}$ The emphasis is ours.

${ }^{4}$ Here "labor" means "productive" work.
} 
cement, among others. ${ }^{5}$ Similarly, many segments of the labor market are noncompetitive. Unionized school teachers prevent progress and efficient use of resources in education, and help retard the growth of workforce productivity.

Mexico has to improve its economic and social institutions in order to compete in the world economy. It has to accelerate the development of its skill base. The inefficiency of its schooling sector, the small fiscal base and the stress on modern Mexican families contribute to the low level and slow growth in the rate of Mexican productivity.

This paper makes these points in the following way. Section II reviews the evidence on the sluggish performance of the Mexican economy. Section III reviews the evidence on the high level of regulation of the Mexican economy. Section IV discusses the high level of monopolization in the Mexican economy. Section V discusses the problem of stagnant labor force productivity and the poor performance of Mexican schools. These are serious problems because human capital accumulation is a major source of economic growth. The growth of single parent Mexican families likely contributes to this problem, and policy should address it. Inequality in Mexico will increase in the next generation if Mexico does not address the growing problem of childhood poverty. Section VI discusses the role of the informal sector in reducing productivity and retarding economic growth. We examine the claims that social protection programs have promoted the growth of the informal sector and that informality reduces productivity and inhibits economic growth. We find that recently introduced social programs have played at best a minor role in promoting the growth of the informal sector. Sector VII summarizes the paper.

\section{II.Performance of the Mexican Economy}

Mexico has displayed poor economic performance since its independence. As evident in Figure 1, Mexico's GDP per capita (in 1990 dollars) in the early $19^{\text {th }}$ century was similar to that of developed countries such as Japan, Great Britain or Germany, and the disparity in economic performance between the U.S. and Mexico was significantly lower than it is today.

\footnotetext{
${ }^{5}$ See Comisión Federal de Competencia [2004], World Bank [2006], Levy and Walton [2009] for comprehensive analyses of these and other sectors.
} 
Figure 1. GDP per capita: 1990 USD PPP's

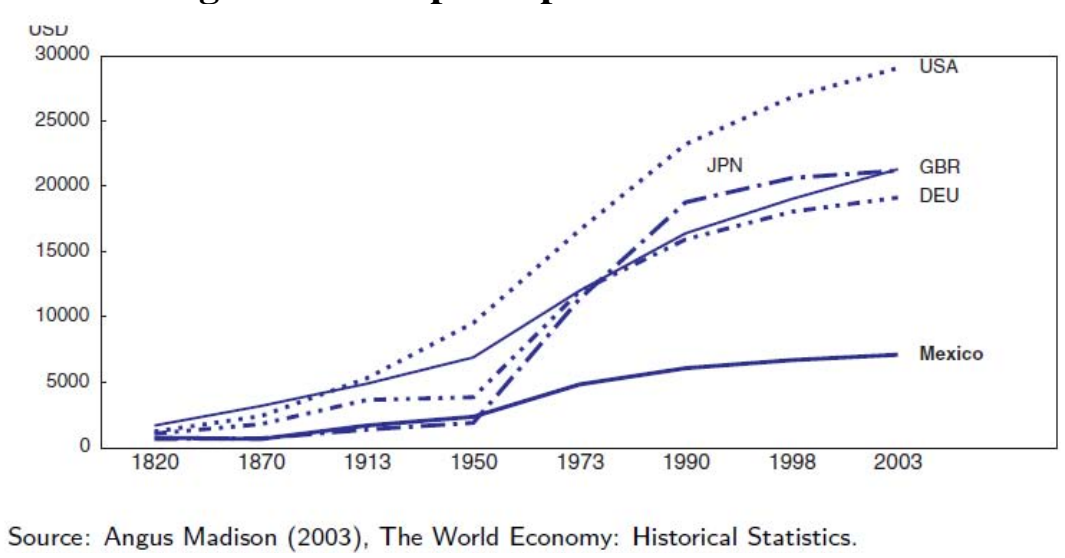

Focusing only on the post-war period, the performance of the Mexican economy has been weak and worse than that of many other countries. For example, the GDP per capita in 1950 was higher than that of Korea, Chile and China. Today, the level is higher for Korea and Chile. China will soon overtake Mexico. (See Figure 2.)

Figure 2. Real GDP Per Capita in US Dollars

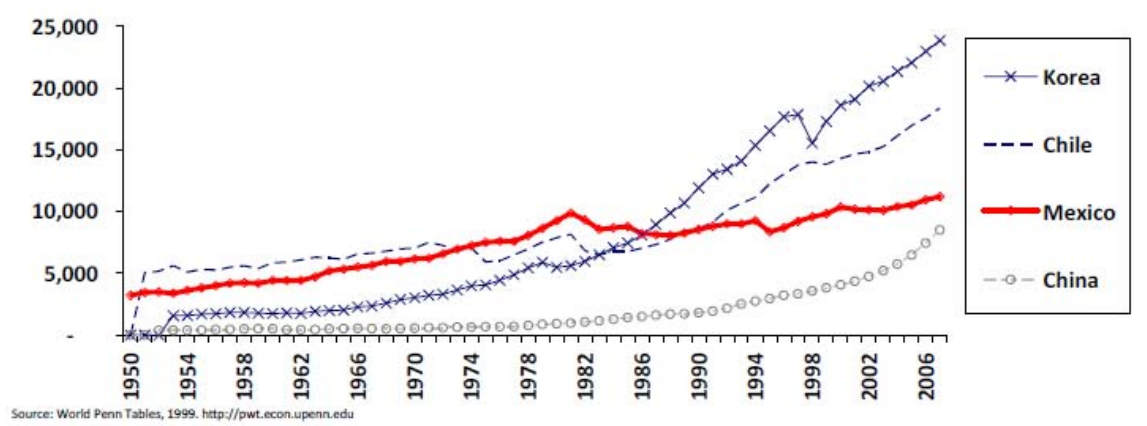

The emergence of China as a key player in international markets has eroded Mexico’s competitive position. NAFTA put Mexico in a good position to produce goods for its partners. It increased its importance as provider of labor and oil. However, this beneficial effect has disappeared. Since the recession of 2000, Mexico has not returned to its previous trend line in the production of goods for the zone. Chinese producers have displaced Mexico as the second largest exporter of goods to the NAFTA market.

According to the OECD[2009], unit labor costs have increased since 1997 due to higher wages and the slow growth of workforce productivity. See Figure 3. Mexico has not improved the efficiency of its labor force and has lost its competitive edge over the last decade. According to the OECD, the reduced competitiveness of Mexico has produced a loss of 270,000 jobs in 
manufacturing. Mexico's trade deficit with China increased and is driven by the low cost of imports. The contribution of labor productivity growth on per capita GDP is negative for Mexico (OECD[2009]). Figure 4a shows that factor productivity steadily increased into the early 1970s, stalled and has declined since the early 1980s. GDP per hour worked (Figure 4b) has also stagnated since that time.

Figure 3. Unit Labor Costs in Manufacturing, Index OECD

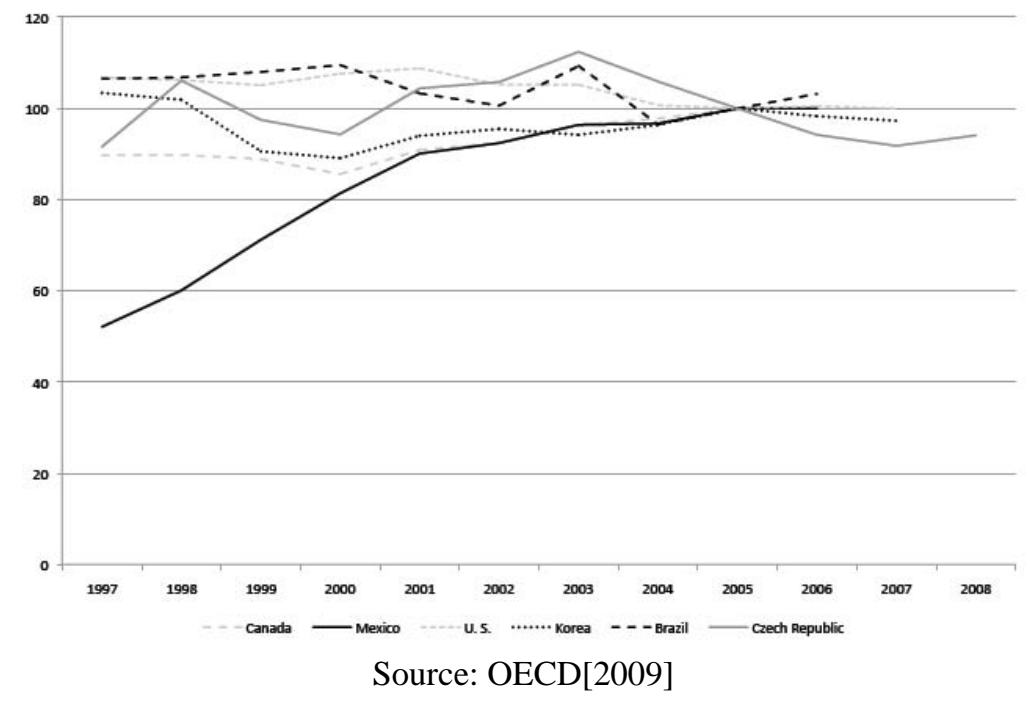


Figure 4.

a. Total Factor Productivity in Mexico: 1950-2006

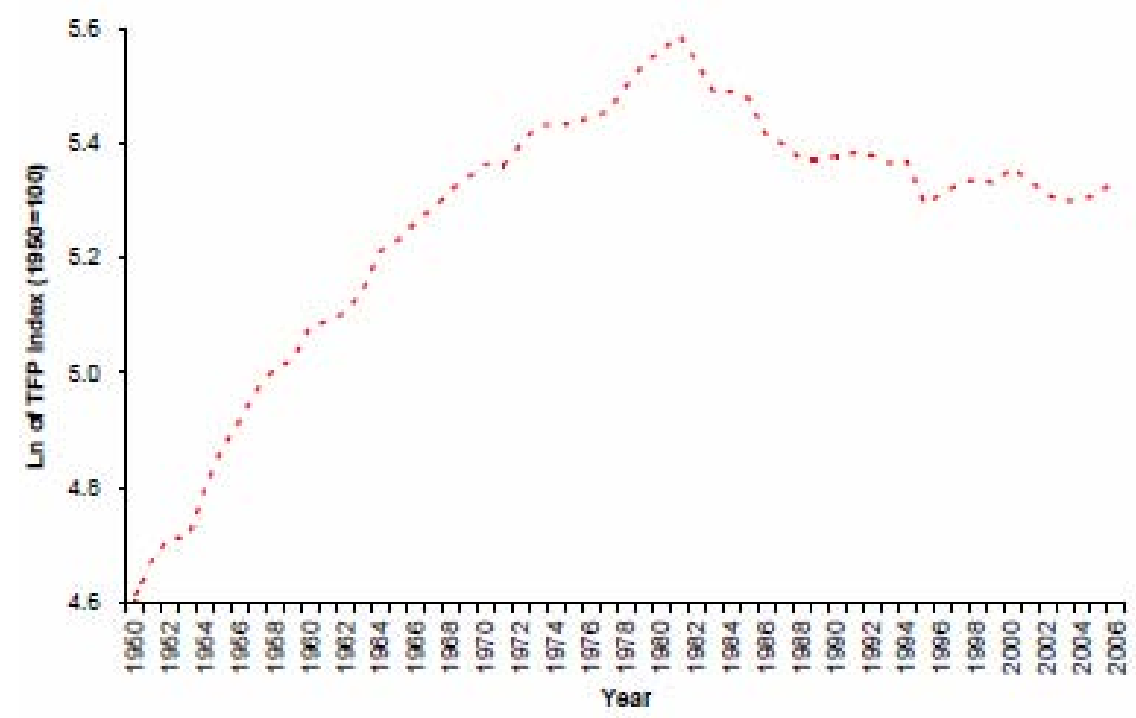

Source: García-Verdú [2007].

\section{b. GDP Per Hour of Work (1990 USD)}

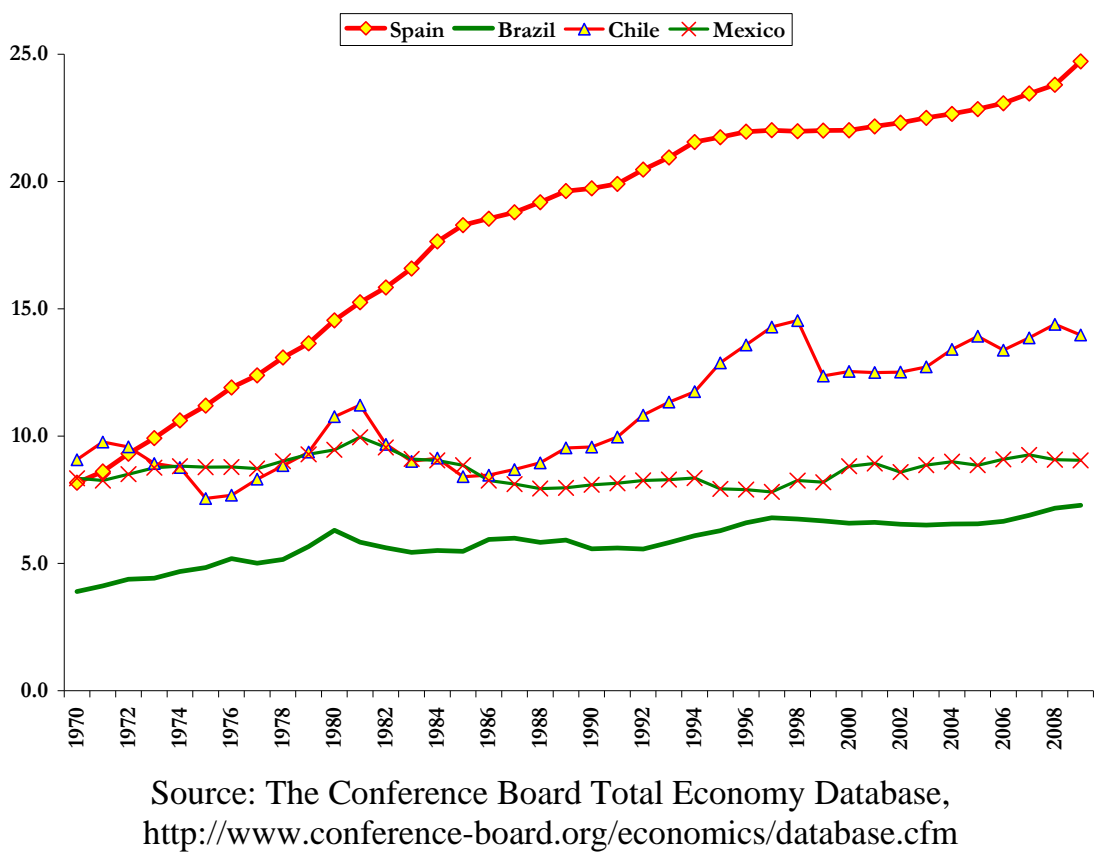

\section{The Mexican Economy is Highly Regulated}

Rigidity and weak incentives inhibit Mexican economic performance. Whatever reforms have been implemented are too small in scale to keep the Mexican economy competitive. Labor markets are very rigid in comparison with other OECD and middle income economies. For 
example, the Mexican laws make it very expensive to hire or fire workers, which directly increases the cost of labor.

Payroll taxes and mandated contributions of firms to the social security sector are high. There are additional high costs of hiring and dismissing workers. Legal procedures to settle disputes between employers and employees are costly and not predictable. Legal disputes are solved at the discretion of councils, which operate erratically and unevenly. The effect of these regulations as a whole makes Mexico the country with the highest labor rigidity among similar less developed countries. Figure 5 shows an international Comparison of the Index of Labor Market Rigidity (0=low, 1=high).

\section{Figure 5. International Comparison: Index of Labor Market Rigidity} (0=low, 1=high)

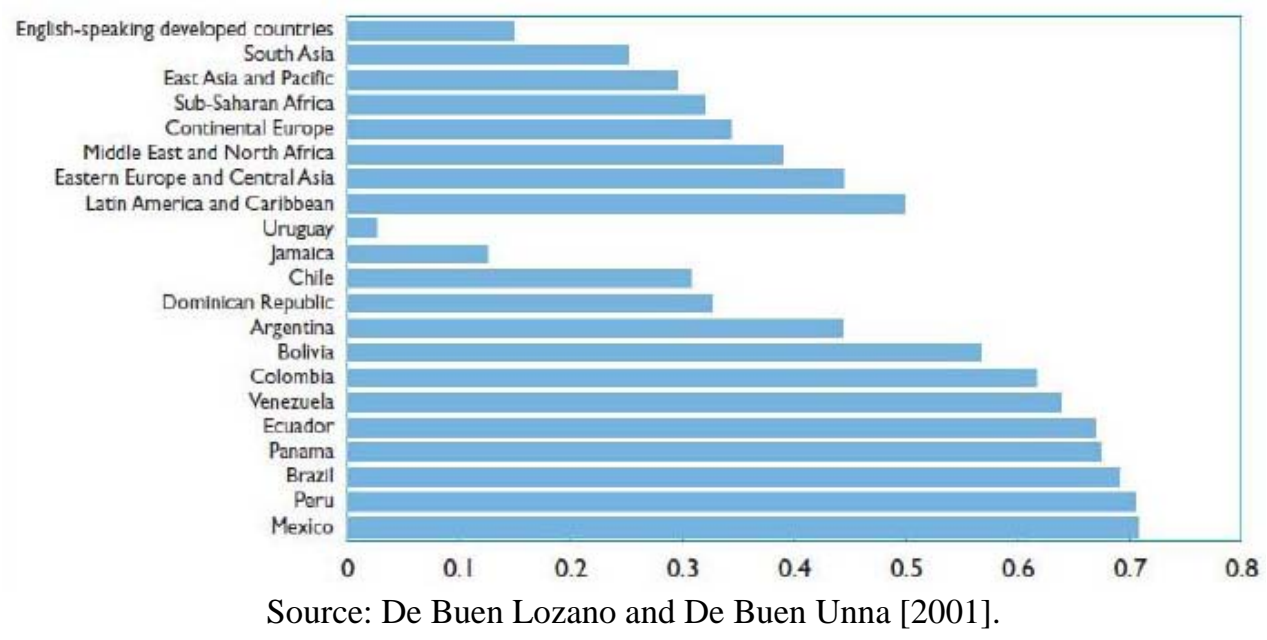

In addition, the cost of enforcing contracts and laws increases the cost of doing business in Mexico. Contracts are difficult to enforce. In comparison with similar countries, it takes more time and money to force a person or firm to comply with a signed contract. According to the OECD, "it takes 421 days and costs 20 percent of the contract value to enforce a contract in Mexico whereas it takes only 75 days and 5 percent of the contract value in Korea”. 6

The slow implementation of legal reforms limits the ability of agents to contract, and the lack of contract enforcement by state and local authorities makes it very difficult to attract investors. Figure 6 compares the cost of enforcing contracts in Mexico in comparison with other

\footnotetext{
${ }^{6}$ OECD[2009].
} 
countries. This cost is 30 percent of total debt values on average, while in countries like Argentina or Brazil it is around 17 percent.

Figure 6. Cost of enforcing contracts, 2007 (as percent of total debt values)

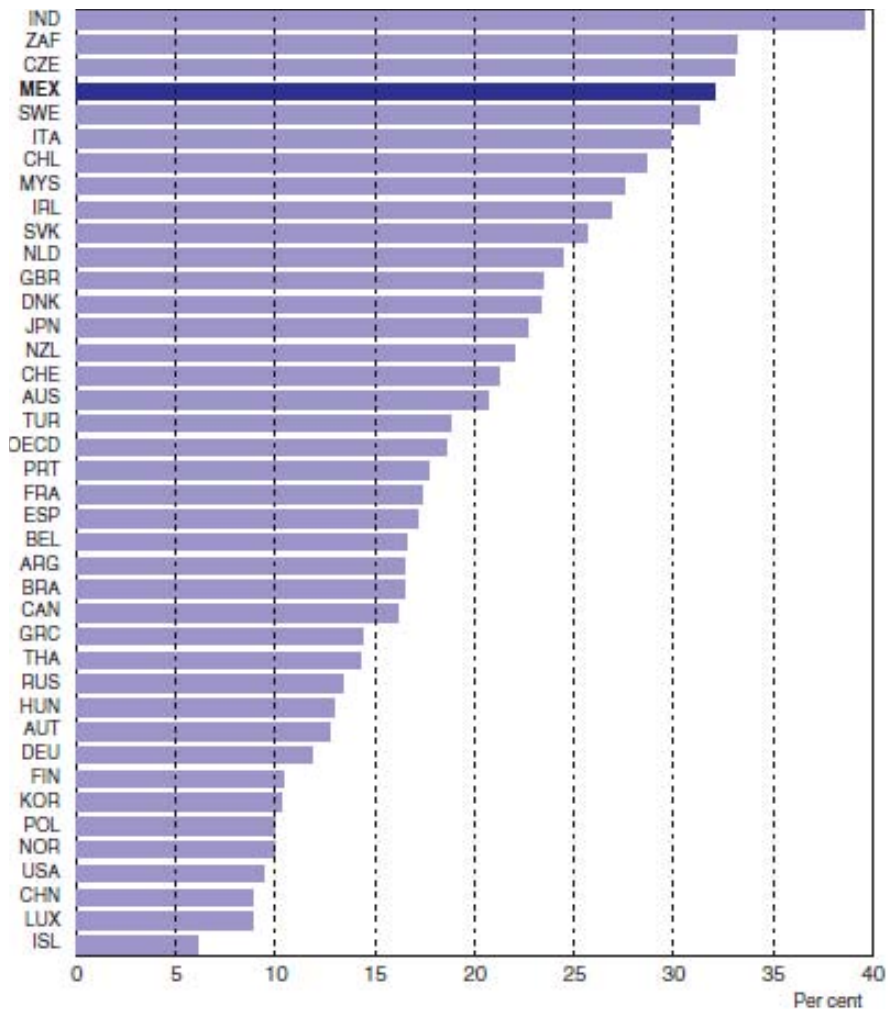

Source: OECD[2009] 


\section{Lack of Competition and Weak Infrastructure}

Its geographic location and trade and investment partnerships should make Mexico a good place to invest. However, the rigidity of its labor market and the pervasive anti-competitive elements in the Mexican economy reduce its attractiveness. They are an aspect of a political and economic culture that has accommodated itself to special interest groups. This culture has been called "Crony Capitalism.” Special interest groups get favors which lead to monopoly and inefficiency.

The lack of a vital infrastructure in communications and provision of energy reinforces the lack of competition in the country. Excessive monopoly and restrictions in these markets and excessive participation of government in the provision of these goods reduces competition.

The literature on energy, transportation, financial services and some goods (i.e. cement) shows high segmentation of these markets and limited competition. This increases production costs and reduces competitiveness of the whole economy. We illustrate the problems created by the lack of competition by examining the telecommunications market, which by many measures is highly monopolized. See Figure 7. The virtual monopoly of Telmex leads to high costs of telephone calls as well as low rates of broadband use, internet usage and investment. See Table 1 and Figure 8.

Figure 7. Market Share in Select Segments of the Mexican Market, 2005

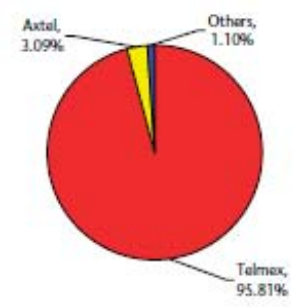

Local Services (\% of Subscriber Lines)

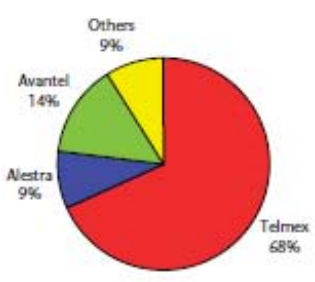

Data

(\% of Service Revenues)

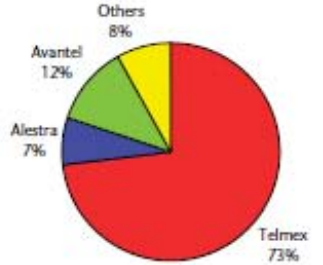

Domestic Long Distance (\% of Minutes)

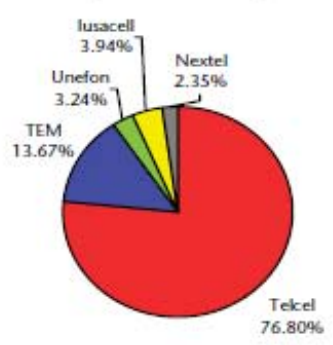

Mobile

(\% of Subscribers)

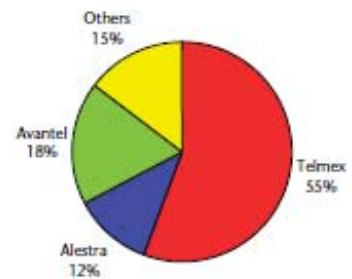

International Long Distance (\% of Minutes)

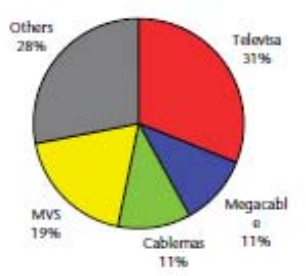

Pay-TV

(\% of subscribers)

Source: Baez [2006]. 
Table 1. Telephone Rates, Selected Countries

\begin{tabular}{lcccc}
\hline Country & $\begin{array}{c}\text { Monthly } \\
\text { rate, } \\
\text { commercial } \\
\text { (US\$) }\end{array}$ & $\begin{array}{c}\text { Monthly } \\
\text { rate, } \\
\text { residential } \\
\text { (USS) }\end{array}$ & $\begin{array}{c}\text { Cost per } \\
\text { connection, } \\
\text { residential } \\
\text { (US\$) }\end{array}$ & $\begin{array}{c}\text { Cost per call, } \\
\text { three minutes } \\
\text { (USS) }\end{array}$ \\
\hline Argentina & 12.94 & 4.56 & 51.72 & 0.02 \\
Brazil & 13.71 & 7.72 & 13.81 & 0.05 \\
Chile & 9.20 & 9.20 & 43.95 & 0.10 \\
Korea, Rep. of & 4.36 & 4.36 & 50.35 & 0.03 \\
Mexico & 18.35 & 14.51 & 104.73 & 0.14 \\
\hline
\end{tabular}

Note: In 2005 USD

Source: Levy and Walton [2009]

Figure 8. Internet and Broadband Penetration as Percentage of Total Accounts, Selected Markets, 2005

$\square$ Internet Penetration $\square$ Broadband as a \% of Internet Accounts

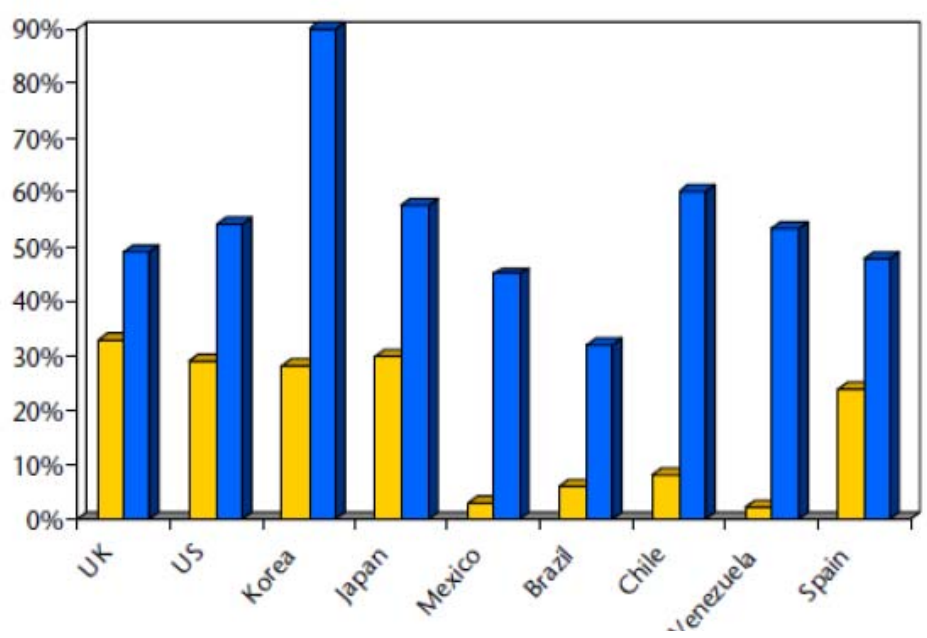

Source: Baez [2006]. 


\section{Understanding the Stagnation of Work Force Productivity}

Mexico has substantially improved the level of education of its workforce (see Figure 9). Yet, as shown in Figures 4a-4b, labor force productivity has not increased. This is due to the inefficiency in the labor market and the poor quality of schooling. Mexico invests a considerable fraction of its resources in education — six percent of its GDP—which is adequate according to OECD standards. However, these resources are not efficiently utilized. In absolute levels, investment per student is low (see Figure 10).

Figure 9. Schooling Attainment in Mexico: 1950-2005

(Percentage of the population 25 years of age and older with given schooling level completed)

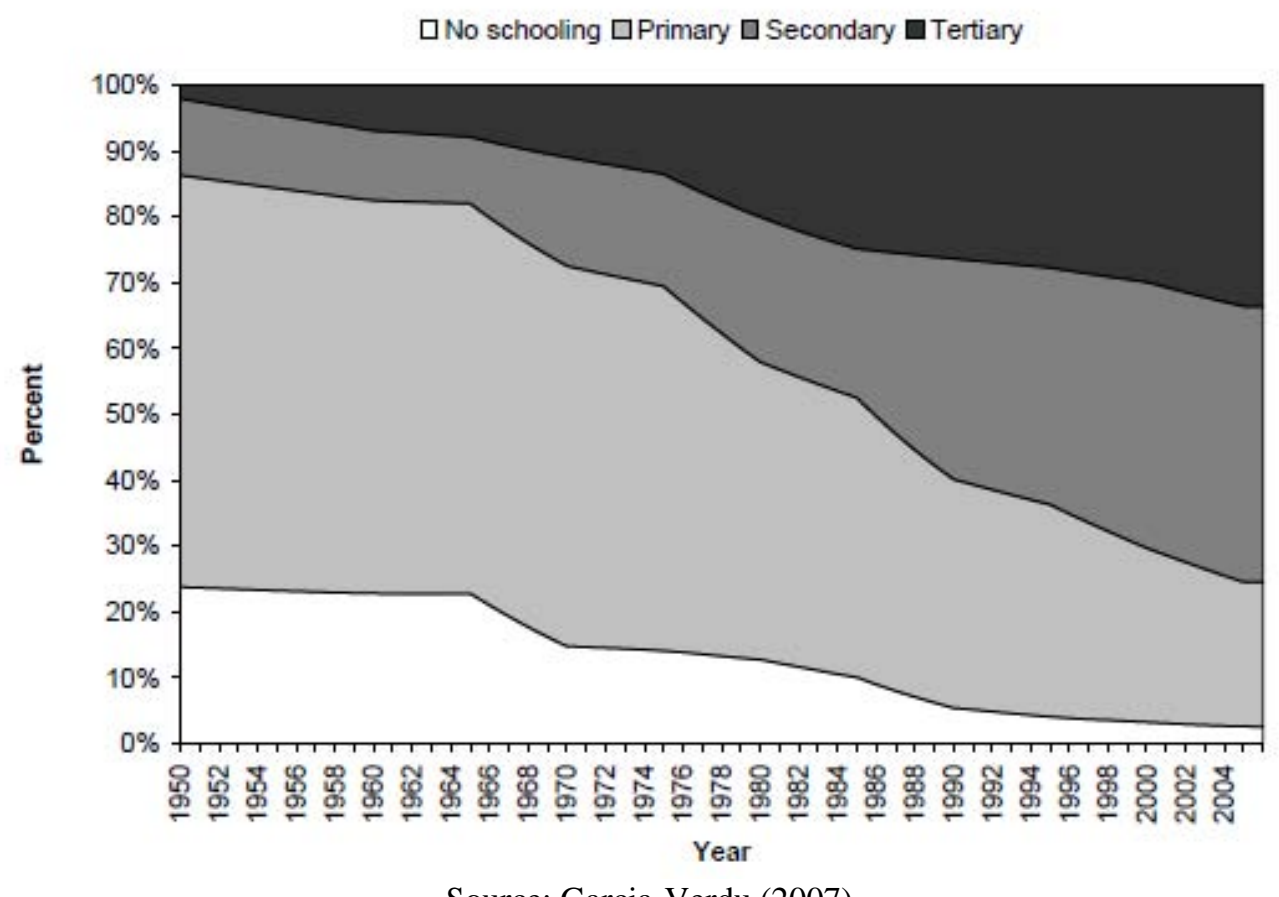

Source: Garcia-Verdu (2007) 
Figure 10. Annual expenditure on educational institutions per student for all services Primary Education 2006)

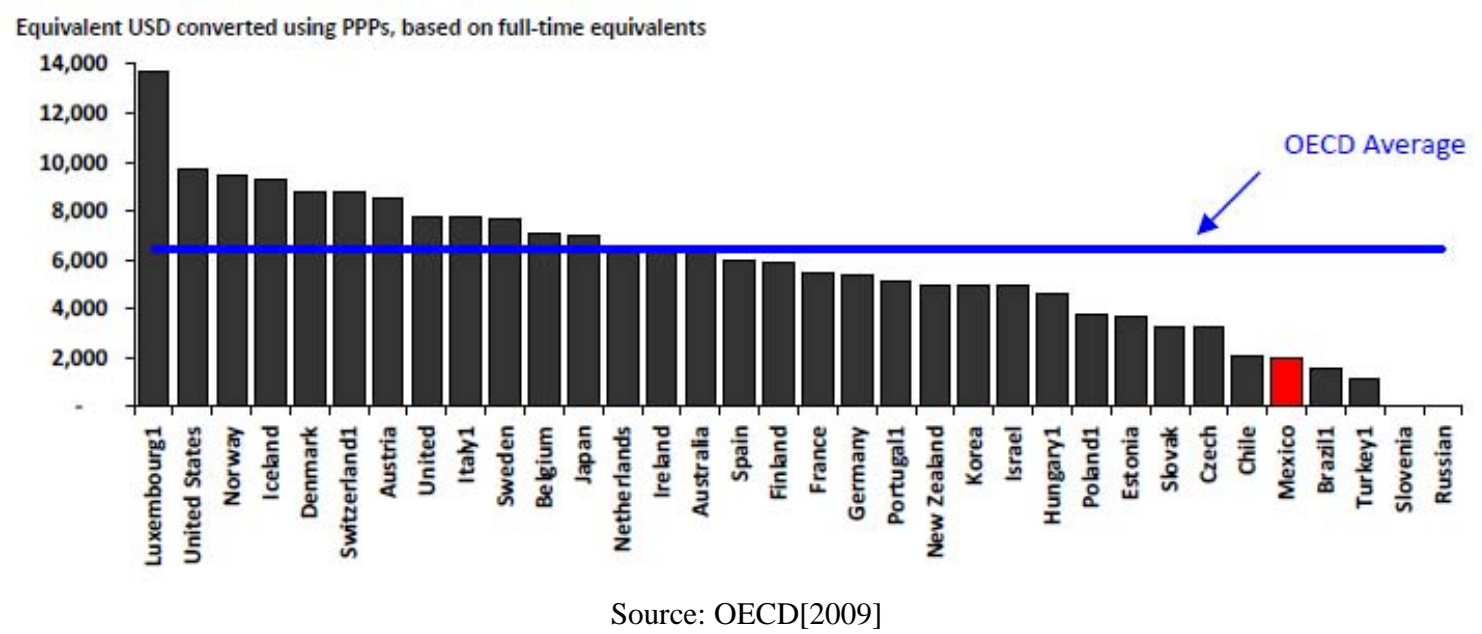

Figure 11. Distribution of current expenditure on educational institutions for primary, secondary and post-secondary non-tertiary education (2006)

$\square$ Compensation of all staff $\quad \square$ Other current expenditure

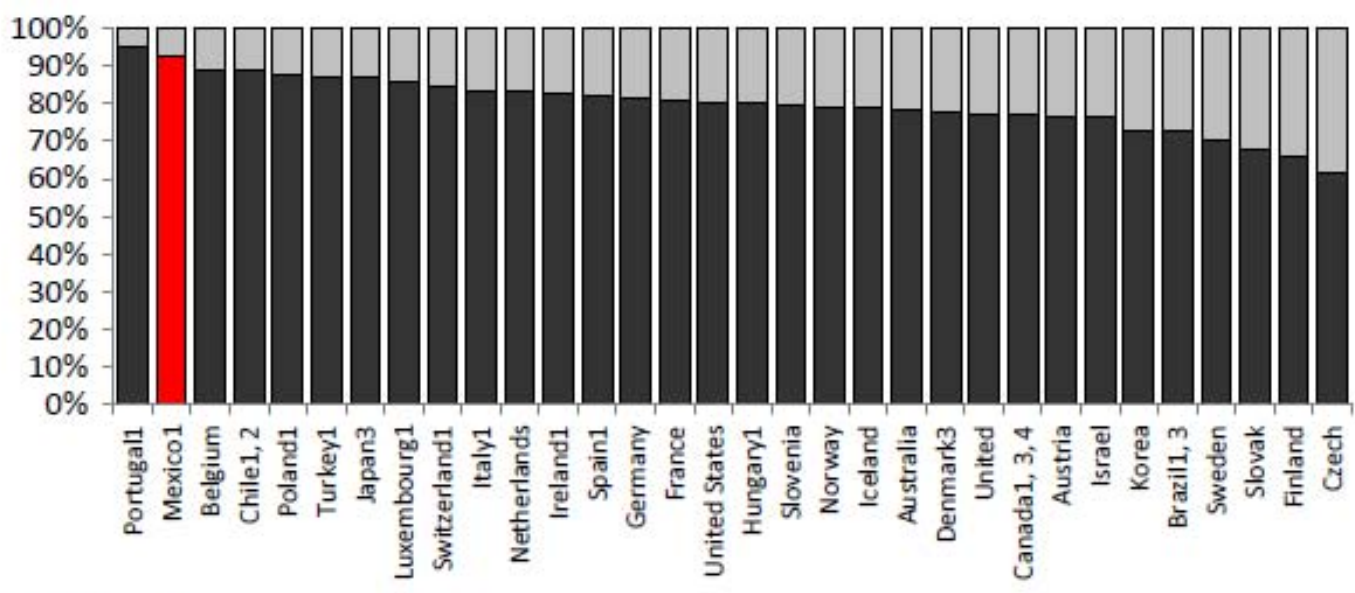

1. Public institutions only.

2. Year of reference 2007 .

3. Some levels of education are included with others. Refer to " $x^{*}$ code in Table B1.1a for details.

4. Year of reference 2005 .

countries are ranked in descending order of the share of compensation of all staff in primary, secondary and post-secondary non-tertiary education.

Source: OECD[2009]

Current institutional arrangements retard the growth of skills and help to explain the low level of labor productivity in Mexico. Nearly 90 percent of expenditure on all levels of education is spent on salaries, which leaves little room for investment in infrastructure (see Figure 11). This 
produces sub-optimal high labor intensity in the education sector, and prevents educational innovations. The need for infrastructure is more evident in higher education, where schools are concentrated in a few locations. The enrollment rate of 50 percent for 15-19 year-olds is among the lowest in OECD countries (see Figure 12).

Figure 12. Enrollment rates of 15-19 year-olds (1995, 2000 and 2007) Full-time and part-time students in public and private institutions

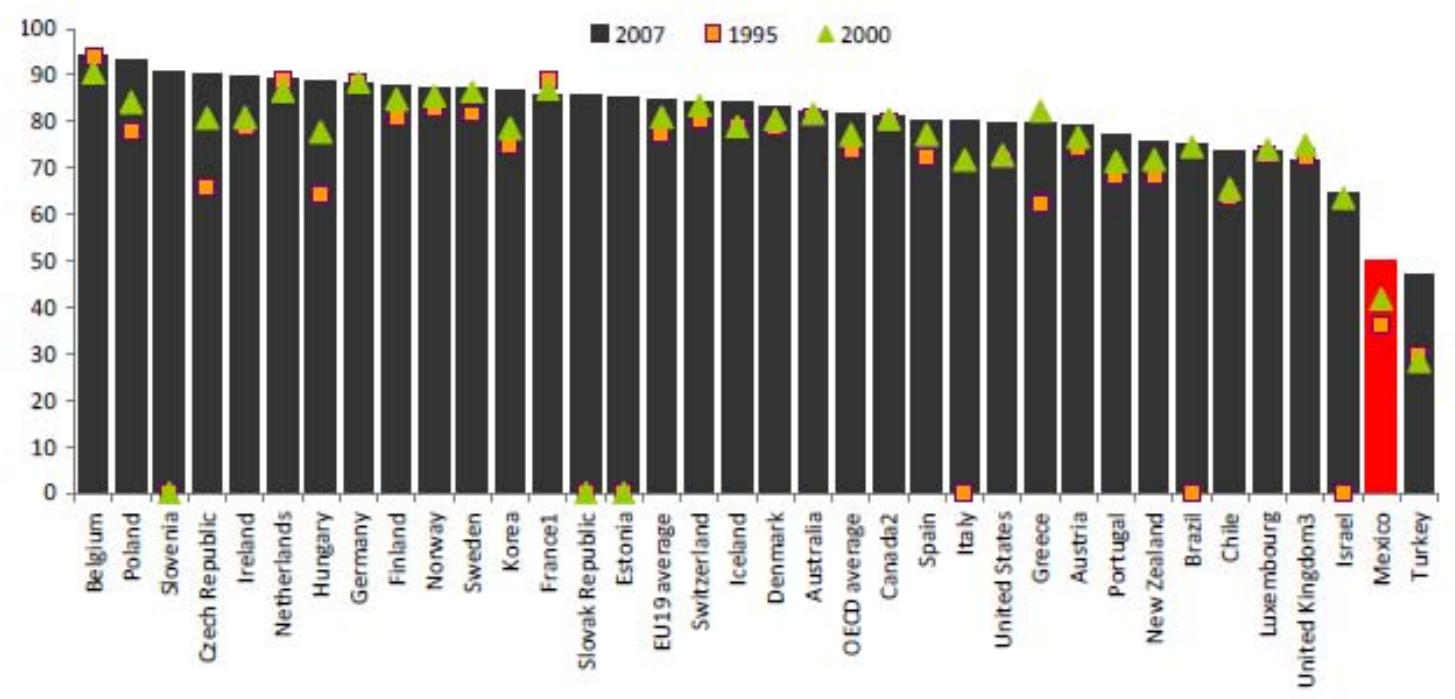

1. Excludes overseas departments for 1995 and 2000.

2. Reference year 2006 instead of 2007.

3. Break in time series following methodological change from 2006.

Countries are ranked in descending order of the enrolment rates of 15 -19 year-olds in 2007.

Source: OECD[2009]

Performance of Mexican students on achievement tests is poor. They have consistently been in the lower end of the distribution of OECD evaluations, even when Latin America countries and transition economies are included in samples. When compared with countries with similar spending, Mexico does not fare well. Russia and Chile spend about the same per student, and achieve higher scores in the PISA examination. (See Figure 13.) ${ }^{7}$

\footnotetext{
${ }^{7}$ A similar level of inefficiency occurs in health care, where more than 10 percent of the total expenditure on health is spent on administrative costs, highest among OECD economies.
} 
Figure 13. PISA score and education spending per student (2007)

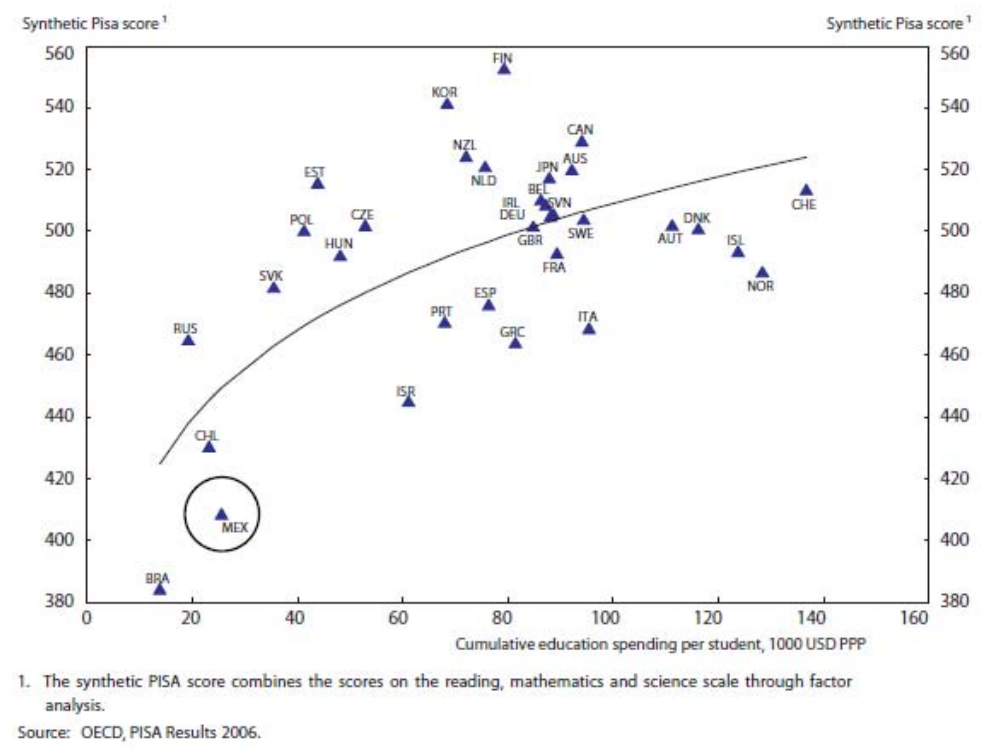

Why is Mexican expenditure on education so inefficient? One major factor is unionism (Mayer-Serra [2009]). Teacher unions absorb a substantial amount of resources in benefits for their members and strongly oppose compensation based on performance. Unions control the hiring of most teachers in the country, and have ample leeway to assign teachers to union activities, diverting resources from education. Unionism retards excellence and protects mediocre teachers. Union efforts undermine attempts to improve accountability through implementation of nationwide exams.

There are additional reasons for the poor performance of Mexican schools and we turn to them next. Since Coleman [1966], it has been known that families are major contributors to the success of children in schools. Mexican families are increasingly under stress.

\section{A. Lack of Attention to Early Childhood Education}

An inefficiency that receives less attention, and likely has large effects on Mexican skill formation, is the lack of investment in the early years of children, particularly for those from disadvantaged environments. Figure 14 shows a consistently small amount of investment in the preschool years over time. ${ }^{8}$ Because of inequality across and within regions, schooling expenditure on disadvantaged children is low.

\footnotetext{
${ }^{8}$ The chart shows a reallocation of resources away from tertiary education toward primary education, which helps to explain the increase in educational attainment in the general population in Mexico.
} 
Figure 14. Public expenditure on education per student relative to primary education $($ Primary $=100)$

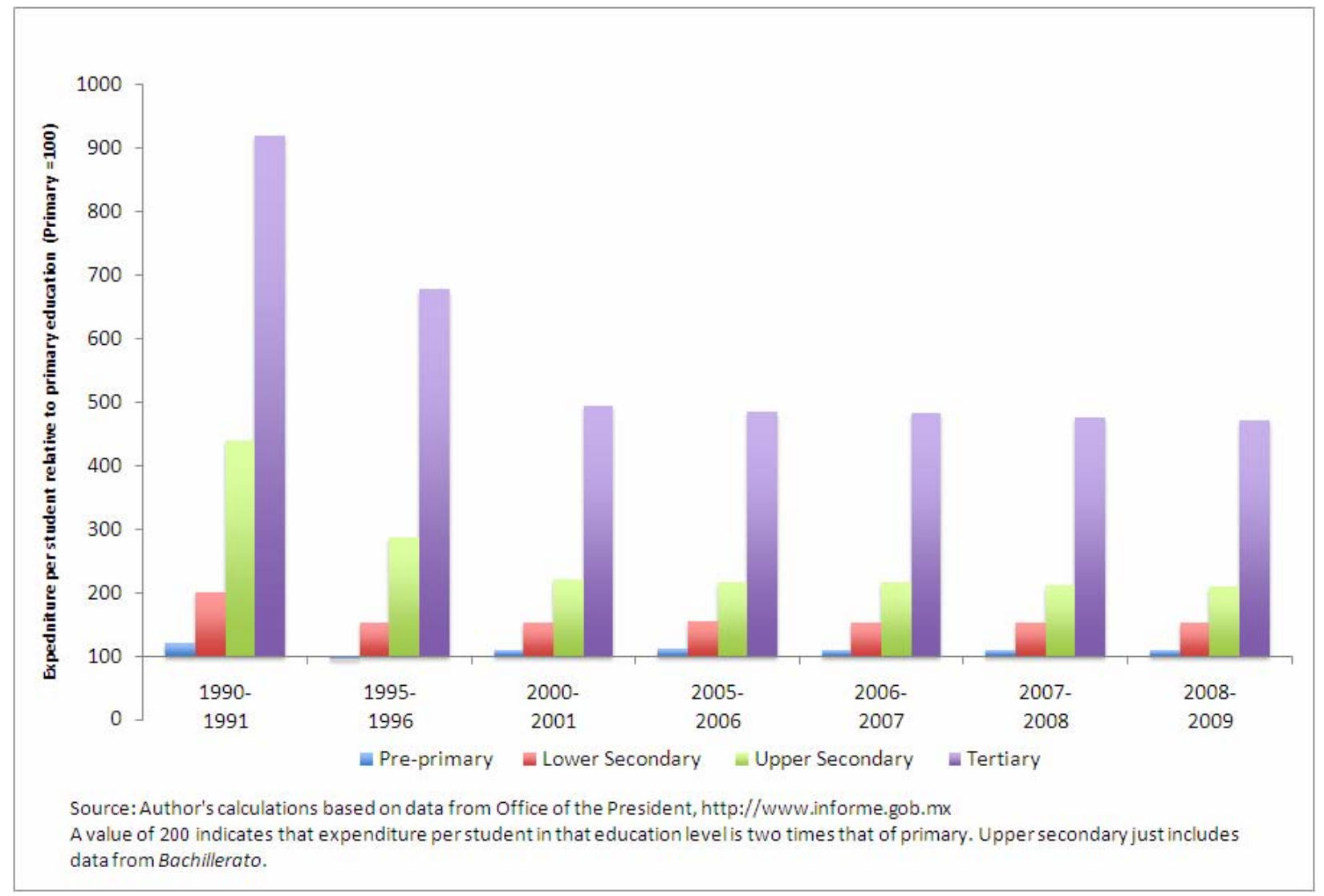

A large body of research in economics, neuroscience, and developmental psychology has produced a better understanding of the technology of human skill formation. (See Cunha and Heckman [2007] and Heckman [2006; 2008].) Four concepts that have emerged from this literature show why the early years are so important, and the nature of the inefficiency we are pointing to. First, the architecture of the brain and the process of skill formation are influenced by an interaction between genetics and individual experience. The modern literature on epigenetic expression teaches us that the sharp distinction between acquired skills and ability featured in the early human capital literature is not tenable. Both abilities and skills are produced and environments play a key role in determining gene expression (Gluckman and Hanson [2005], Rutter [2006]). Second, the mastery of skills that are essential for economic success and the development of their underlying neural pathways follow hierarchical rules. Later attainments build on foundations that are laid down earlier. This stems from two characteristics of the nature of learning. Early learning confers value on acquired skills, which leads to self-reinforcing 
motivation to learn more. Early mastery of a range of cognitive, social, and emotional competencies makes learning at later ages more efficient and therefore easier and more likely to continue. It is well documented that gaps between the advantaged and disadvantaged in the cognitive and non-cognitive skills of their children emerge early (by ages 4 to 6) before the children enter school, and persist throughout the lifetime (Carneiro and Heckman [2003], Cunha et al. [2006]). Evidence from Mexico is consistent with evidence from the U.S. Figure 15 shows that IQ test gaps between children of educated mothers and those without emerge early in life and are substantial. These gaps persist over life. Schools barely budge these gaps. The gaps are not solely caused by genes but are also shaped by family environments, and can be remediated by early intervention (Cunha and Heckman [2009], Heckman et al. [2010b]).

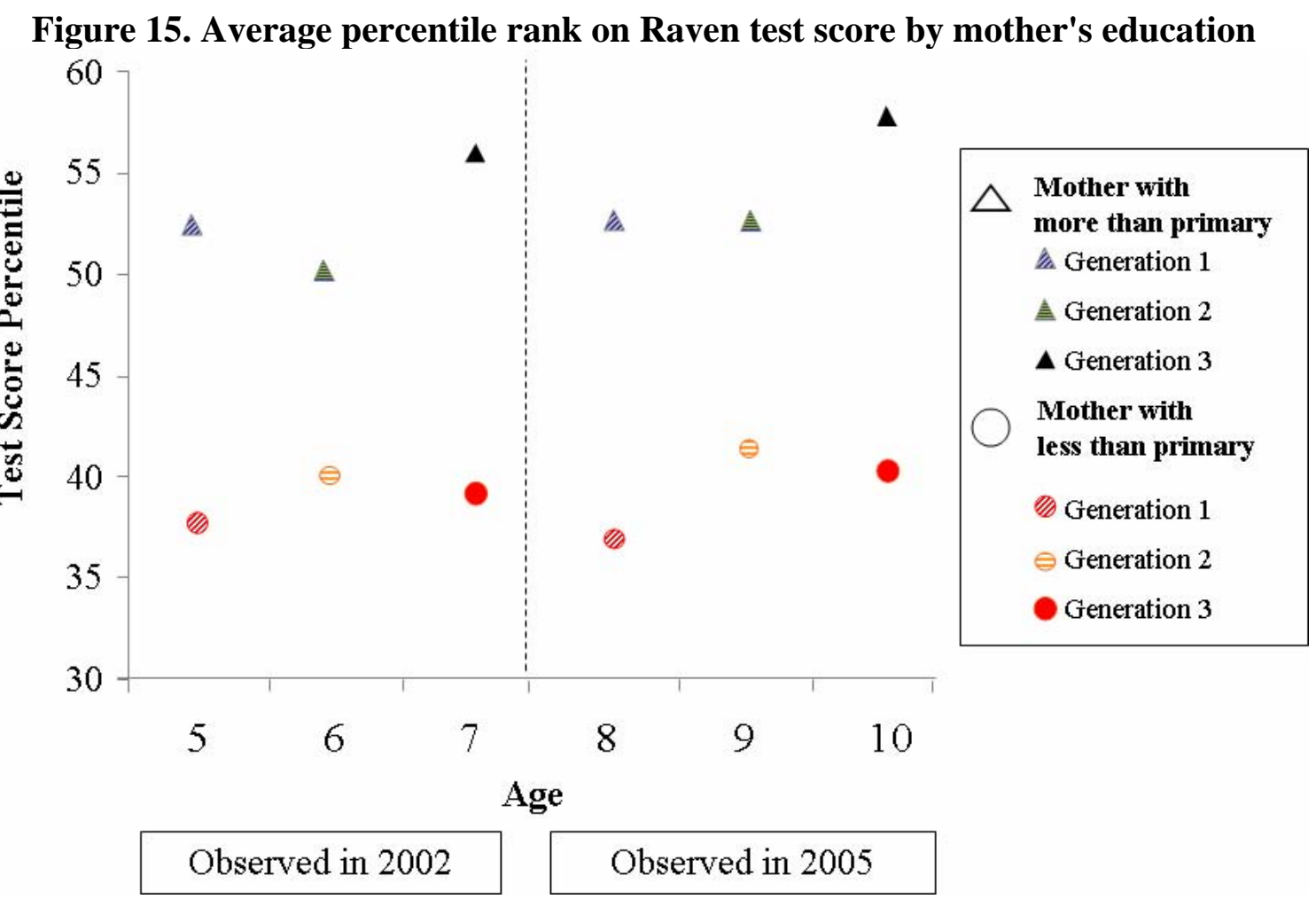

Source: Author's calculations using MXFLS rounds 2002 and 2005. Percentiles are constructed for each age based on raw scores. Raven is a measure of IQ.

Note: The circles represent three different cohorts of children with mothers with less than primary education observed in two points in time. In the first period (2002), they were aged 5 to 7 years old, and 8 to 10 in 2005. The triangles three different cohorts of children with mothers with less than primary education observed during the same periods and with the same ages.

Third, cognitive, linguistic, social, and emotional competencies are interdependent. All are shaped powerfully by the experiences of the developing child. All contribute to success in 
society at large. While the role of cognitive skills in determining socio-economic success has received a lot of attention, non-cognitive skills, such as self-control, perseverance, and motivation, have also proven to be powerful predictors of outcomes such as high school graduation rates, earnings, achievement test scores, divorce rates and crime (Heckman et al. [2006], Borghans et al. [2008], Heckman et al. [2010a]).

Finally, although adaptation continues throughout life, human abilities are formed in a predictable sequence of sensitive periods, during which the development of specific neural circuits and the behaviors they mediate are the most plastic and therefore optimally receptive to environmental influences. Sensitive periods have been established in the formation of cognitive skills, before age three, where interactions among nutrition, stimulation and the environment play crucial roles. For example, a study of institutionalized Romanian children that had received little or no stimulation, shows that their brain development was well below that of an average child by age three (Rutter and O'Connor [2004]). The earlier they were adopted out into healthier environments, the easier it was to achieve remediation in their development. Similar effects were found in a study of girls in orphanages in South Korea with different levels of malnutrition (Winick et al. [1975], Lien et al. [October, 1977]). Those adopted into a middle-income household, before age two, achieved higher levels of cognitive development compared to those adopted later. Timing in childhood investment matters.

Because of the dynamics of skill formation, skill begets skill, and investments in the early years are more productive than those in later years, particularly investments in disadvantaged children. Figure 16 summarizes the central message of a large literature on the optimal timing of investment. There is no equity-efficiency tradeoff when investing early in the lives of disadvantaged children. Early investments lay the foundation for later investments. Although remediation for early deficits can be achieved later, say by adolescent interventions, it is costlier (see Cunha and Heckman [2006]). Hence, placing too much investment in later ages is inefficient if one is trying to level the playing field for those placed in the most disadvantaged situations by the accident of birth. Mexico under-invests in the preschool years compared to the later years. See Figure 17. Most investments from government interventions are concentrated in elementary and secondary education. The life cycle pattern of investment actually made in Mexico is the 
reverse of what is implied by Figure 16 - that relatively more should be invested in the early years.

In the case of Mexico, this issue is especially important since an increasing proportion of children are being born into poverty with unfavorable family environments. See Figure 18. Current policies toward early childhood do not address these gaps and promote inequality in society for the next generation. 
Figure 16. Rates of Return to Human Capital Investment

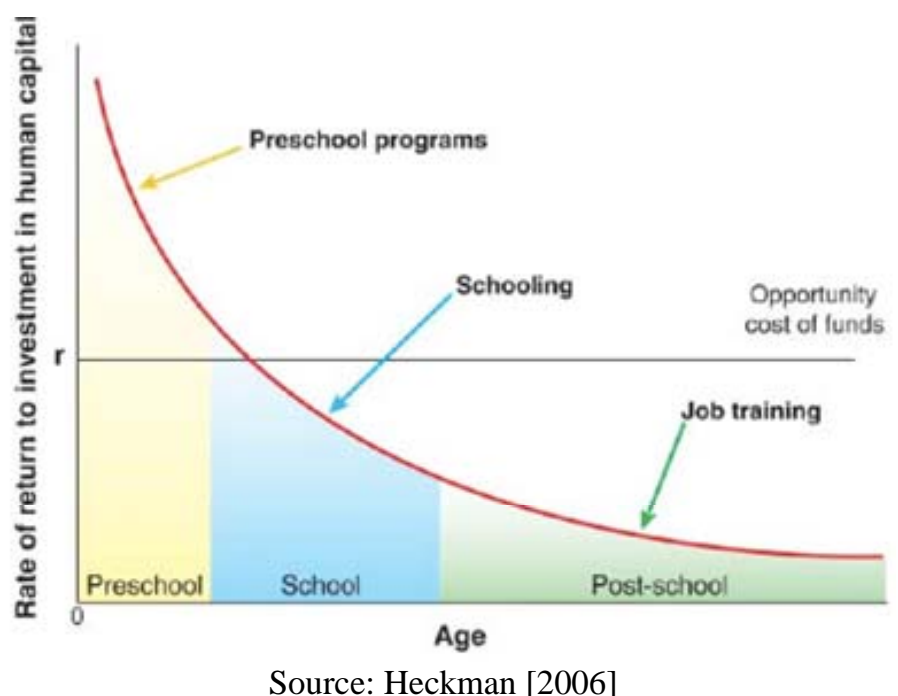

Figure 17. Expenditure on educational institutions as a percentage of GDP, by level of education (2006)

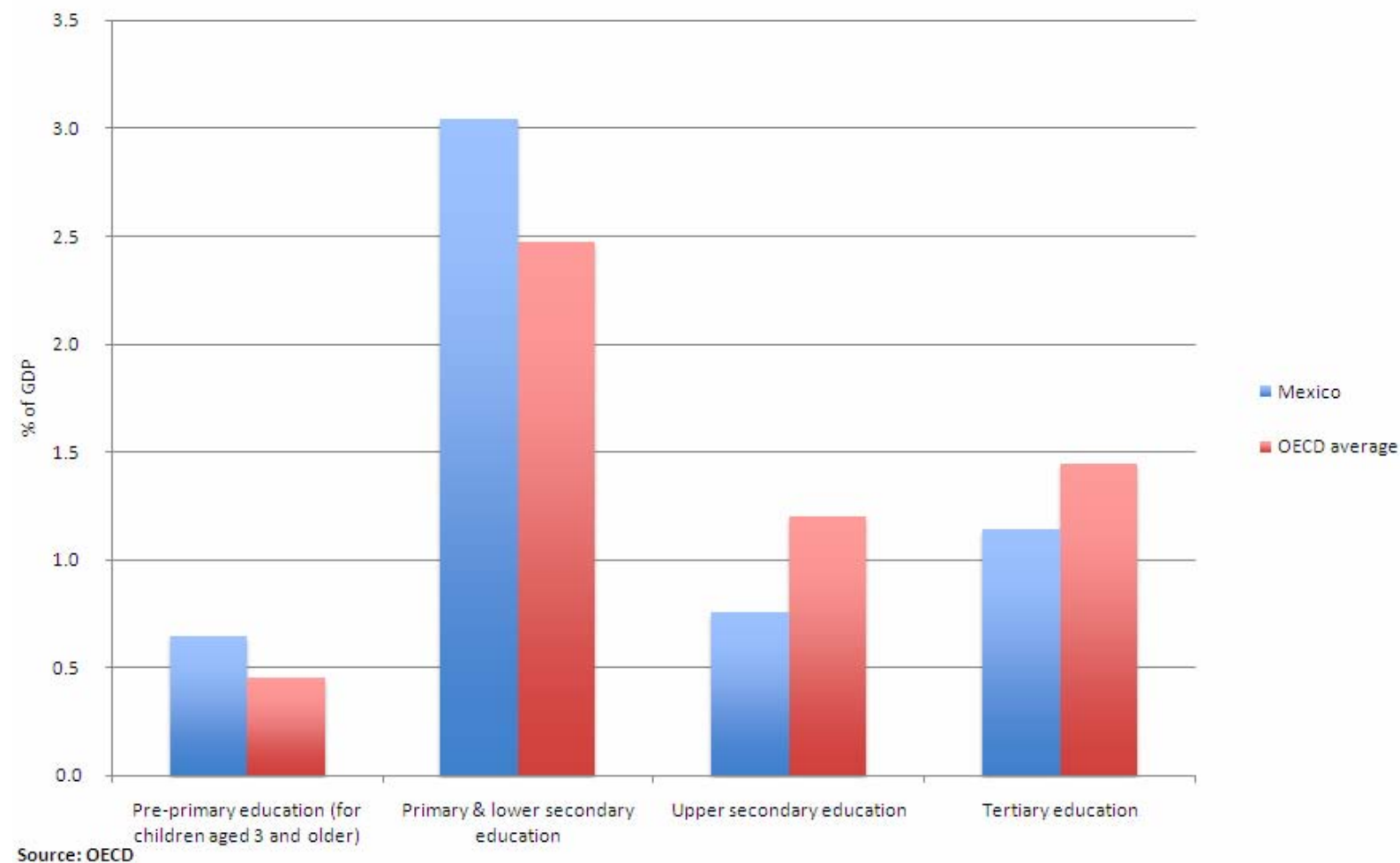


Figure 18. Percentage of Children Living Under Poverty

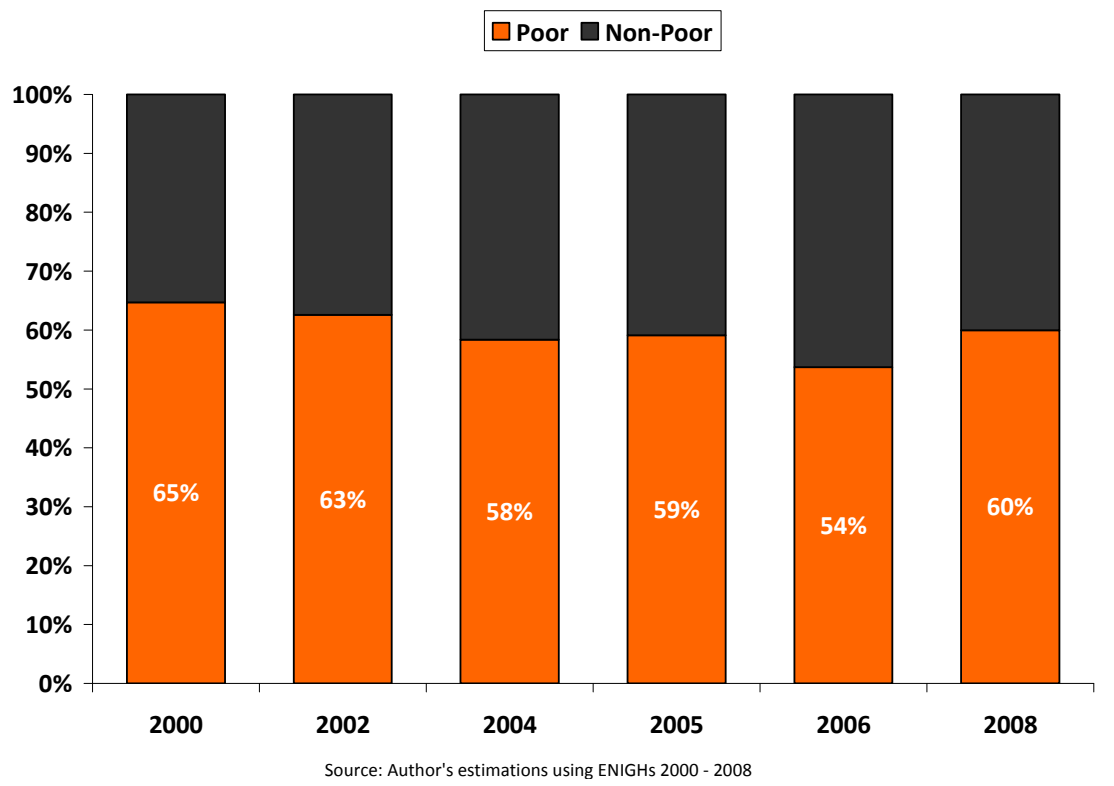

\section{B. Mexican Families are under Stress}

Family environments play a crucial role in promoting skill formation (Cunha and Heckman [2009]). Families determine the resources invested in their children and influence child development by determining the amount of parenting and stimulation they provide to their offspring.

A primary disadvantage for child development is the lack of cognitive and non-cognitive stimulation given to young children. It is not simply a lack of financial resources (Cunha and Heckman [2009]), although poverty may be a cause of the lack of parenting. Family factors play a major role in shaping child outcomes (Cunha and Heckman [2007; 2008], Moon [2010]).

Significant changes in the structure of Mexican families are producing more children born into adverse environments. Some of the adverse trends that have emerged in recent years are increases in the number of children born into poverty, more births that occur out of wedlock, an increase in teenage pregnancy, more children living with single female-headed households, and more children in households with a partner absent due to migration. All of these trends indicate a transformation of the family in Mexico, and its role in child development, that likely reduces the amount of financial resources available for children and the quality of parenting. These environments have been shown to negatively affect child outcomes (McLanahan [2004; 2009], Cunha et al. [2006]), and that is why we focus on them. 
An increasing proportion of children is being born out of wedlock in Mexico in recent years. (See Figures 19, 20 and 21.) The percentage of registered births from cohabiting couples has increased nearly twenty percentage points in the period between 1985 and 2007. Cohabitation does not necessarily create an adverse environment per se, but it is generally associated with less stable unions compared to legal marriages (García and Rojas [2001], Solís and Medina [1996]). Partnership instability influences child emotional development, and has been related to increased maternal stress and health problems, which usually lead to poor parenting behaviors (McLanahan [2009]). Weaker families invest less in their children (Moon [2009]). Cohabitation in Mexico is more common in rural areas among younger, uneducated couples (Quilodrán [2000]). Some cohabitating couples transit to legal marriages, but the overall duration of the unions is shorter (García and Rojas [2002]).

Figure 19. Registered Births in Mexico. Marital Status of Mothers

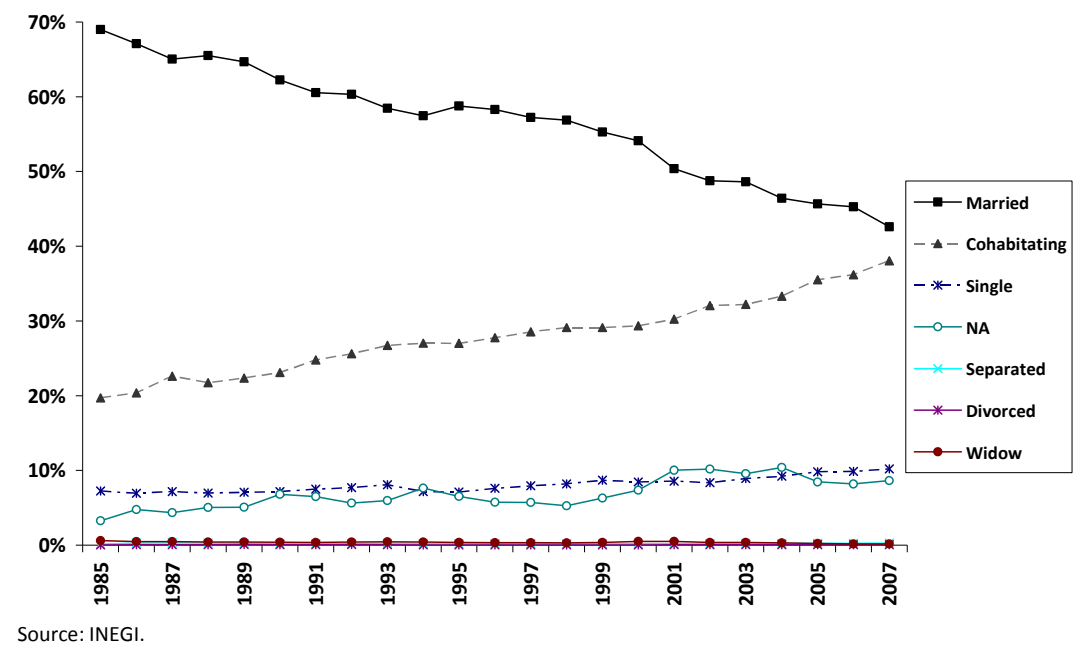

Another relevant trend is the increase in the proportion of female-headed households ${ }^{9}$. (See Figure 20.) The percentage of this type of household increased from $14.6 \%$ in 1992 to nearly 25 percent in 2008. Female-headed households are a heterogeneous group. It is important to differentiate those with young children and headed by single mothers. The proportion of households headed by unmarried females is rising and, with it, the adversity of child environments (see Figure 21). An increasing proportion of these households lives in poverty, although the majority does not (see Figure 22).

\footnotetext{
${ }^{9}$ Here the definition of headship is self-declared, and it is not necessarily economic headship, that is, it does not necessarily identify the individual that provides the greater amount of economic resources to the household.
} 
Figure 20. Percent of Households Headed by a Female

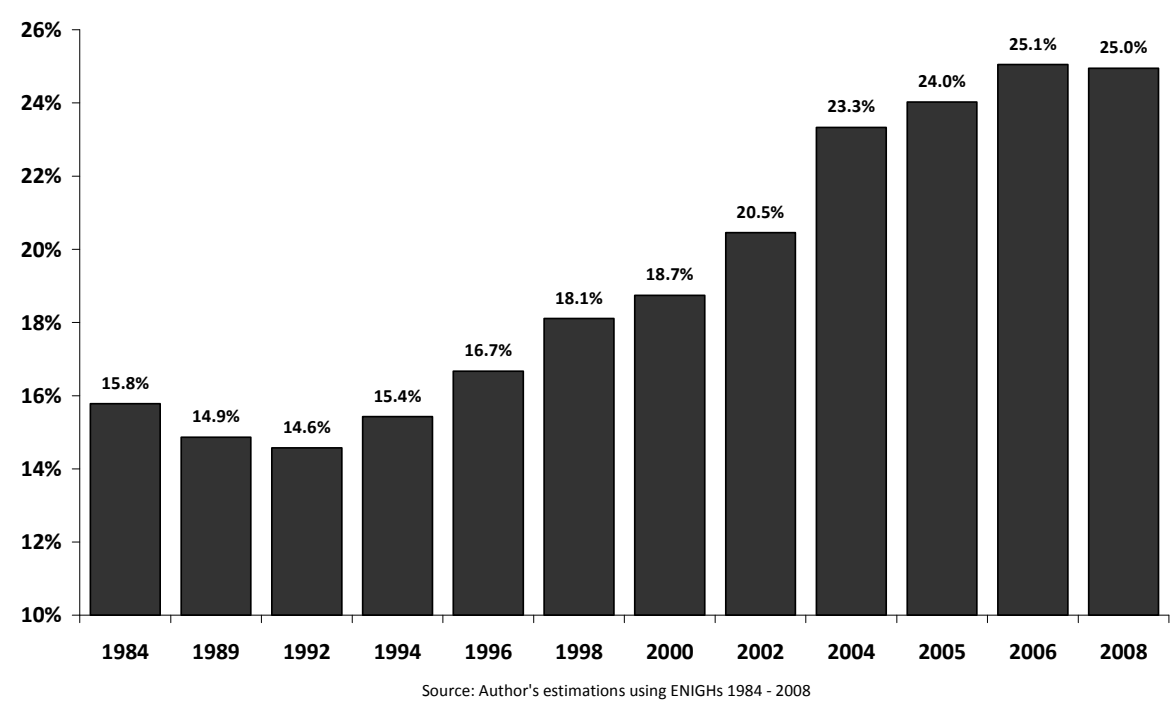

Figure 21. Percent of Households Headed by a Female Not Married

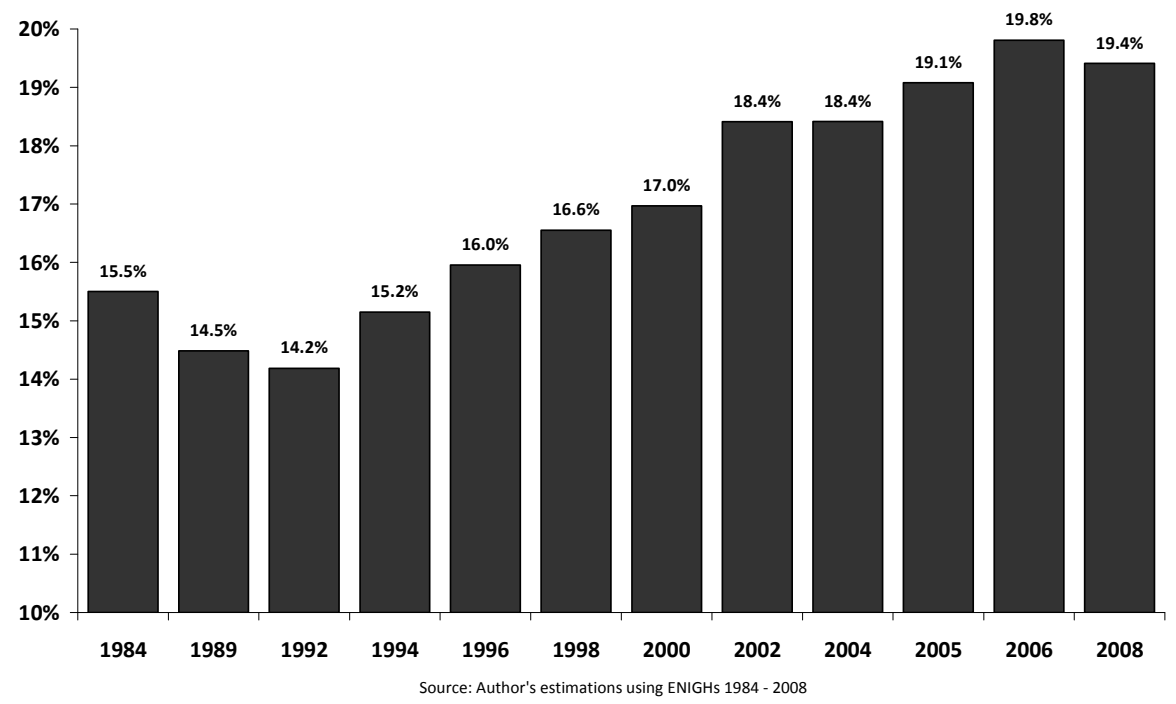

According to Parker and Gómez de León [2000], female-headed households are mostly formed by older women. ${ }^{10}$ They have lower levels of education compared to those headed by males, and have higher labor force participation rates as compared to other women, but lower than those of male-headed households. However, female heads who participate in the labor market have, on average, more precarious employment (they are mainly self-employed), earn lower income, and work more hours (Parker and Gómez de León [2000], Cortés and Rubalcava

${ }^{10}$ A large fraction, roughly 40 percent, are widows. 
[1995]). ${ }^{11}$

\section{Figure 22. Percent of Households Headed by a Female Not Married (by Poverty Status)}

$\square$ General $\square$ Poor

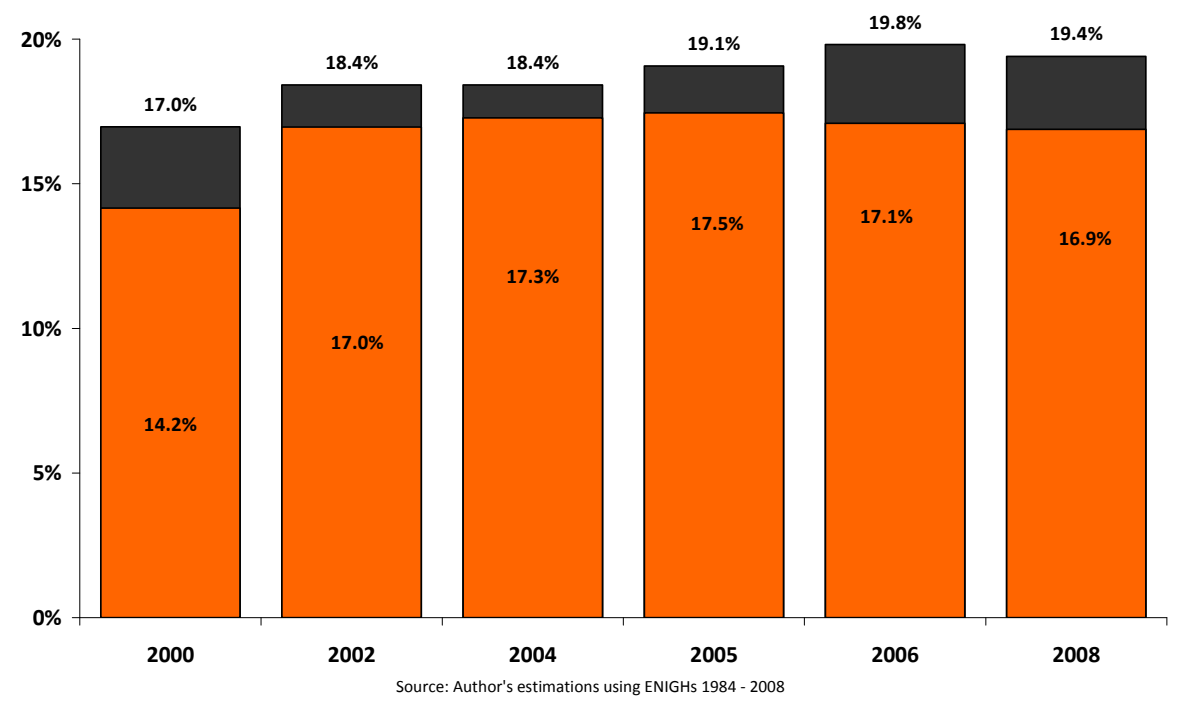

The lack of an earning partner in female-headed families reduces family resources. The reliance on non-labor income increases their vulnerability. Therefore children in these families face hardships and are pressured to enter the labor force earlier. Working mothers have a reduced amount of time to spend with their children, unless they have access to networks or child care substitutes for their parenting. Female headship has been found to be associated with lower

${ }^{11}$ Contrary to what often happens in more developed countries, female-headed households have higher income than those headed by males, particularly in rural areas, and have a lower probability of being poor holding everything else the same (Cortes [1997]). This well-documented fact has puzzled researchers, but recent evidence suggests that the main reason for this is that social and family networks play crucial roles in supporting these households. Nonlabor income, in the form of transfers either from other households or abroad, constitute a significant portion of their income (Parker and Gómez de León [2000], Villarreal and Shin [2008]). Villarreal and Shin [2008] point out that there is also a selection effect that explains their higher income. Those women who are more likely to maintain a household through access to networks are the ones observed as household heads. Nearly fifty percent of single mothers in Mexico in 1997 lived in households where another member was the head, usually one of their parents. These women are younger and have lower levels of education compared to those that are heads (Pérez [2008]). 
school attainment among boys aged 12-17. There is no clear effect for girls (Parker and Gómez de León [2000], Giorguli Saucedo [2002]). In this type of household, children of these ages, regardless of gender, have been found to be more likely to participate in the labor force (Parker and Gómez de León [2000], Giorguli Saucedo [2002]).

There has also been a slight increase in the proportion of teenage births. In 2003, 6.2 percent of registered births were from women younger than 18. The figure was 7.2 percent in $2008{ }^{12}$ Although the increase is small, the trend is not favorable for the growth of labor force quality in the next generation. Teenage motherhood has negative consequences for child development. Evidence from Mexico shows that the children of teenage mothers have greater levels of malnutrition, lower levels of psychosocial and language development, and more behavioral problems (Buvinic [2000]). See the discussion in Cunha and Heckman [2009], Heckman [2008] and Moon [2009].

Figure 23. Average Annual Flows of Mexican Migrants to the US (Thousands)

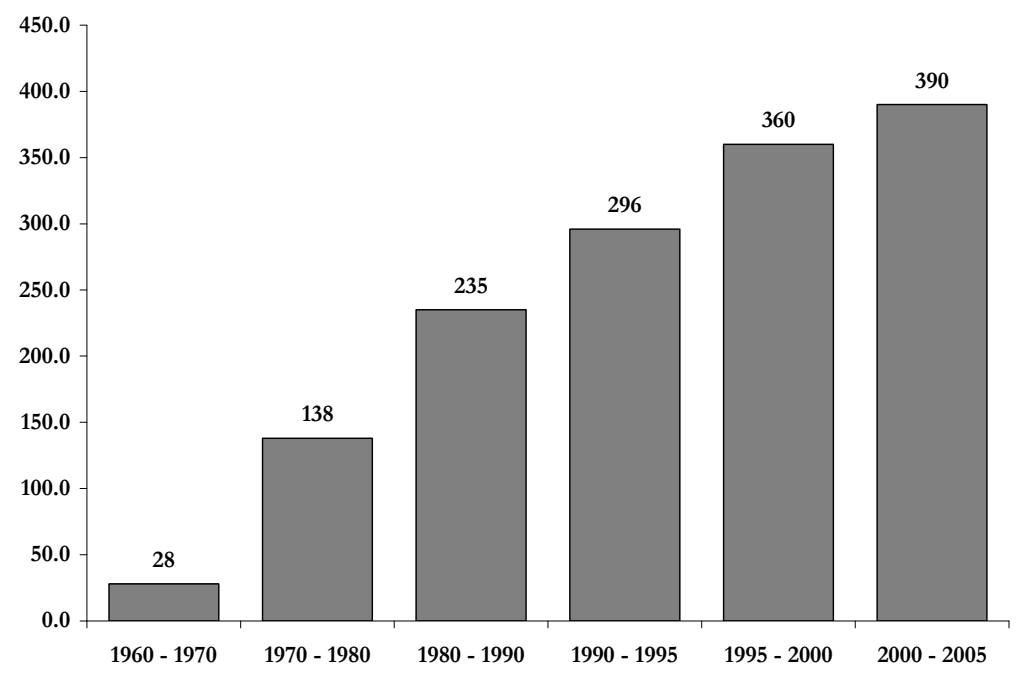

Source: National Mexican Population Council. http://www.conapo.gob.mx

Finally, as a result of a growing number of migrants within and outside the country, a different type of Mexican household is emerging, where a member of the couple (usually the male) is absent for long periods of time. Migration to the U.S. has increased greatly (see Figure 23). ${ }^{13}$ The poorest regions contribute the most migrants. Migration increases the monetary

\footnotetext{
${ }^{12}$ See INEGI natality statistics.

${ }^{13}$ Hernadez-Leon and Zúñiga [2006]
} 
resources available to households and this is a force for increasing investment in children. When heads migrate to the U.S., their families experience less infant mortality, a lower probability of malnutrition, and less poverty (McKenzie and Hildebrandt [2005], Mora Rivera [2007]). However, migration also reduces the time parents spend with their children. The net effect of migration of the head to the U.S. on the educational attainment of the children left behind is not clearly established in the literature (Hanson and Woodruff [2003], McKenzie and Rapoport [2006], Meza González and Pederzini Villarreal [2009], Boucher et al. [2005]). This is a topic that requires much further study.

Current spending on programs to help the poor in Mexico is mistargeted. The main social program designed to aid children in poverty is Progresa/Oportunidades. This program is designed to increase school attendance starting in the elementary years, and focuses on health and nutrition in the years before schooling. The weak effects of the program that have been found for cognitive development likely arise because it starts too late. ${ }^{14} \mathrm{~A}$ good step forward in Mexican policy is that pre-school for 3 year olds was made mandatory starting in 2009, although much remains to be done to achieve universal coverage and to enhance quality. Mexico needs to understand the importance of the early years. It needs to recognize the greater stress under which many Mexican families now operate. It should invest in the family lives of its disadvantaged children. Such investments will promote growth in labor force quality and will also reduce inequality in the next generation.

\footnotetext{
${ }^{14}$ See Behrman et al. [2000], Gertler and Fernald [2004], Behrman et al. [2006], and Fernald et al. [2009].
} 


\section{The Informal Sector: Its Origins and Its Consequences}

Mexico has a large informal sector. It is widely held that the informal sector causes static and dynamic inefficiency (Levy [2008]). But the evidence in support of this claim is surprisingly weak. The category "informality” masks a diversity of categories with different trends and different productivities. Informality is a world-wide phenomenon found in both rich and poor countries (Italy and Peru). Mexican policy makers should never lose sight of the central fact that everywhere around the world, informality is primarily caused by regulation and levels of taxation.

In a recent paper, La Porta and Shleifer [2008] summarize three leading approaches to the study of informality in the literature. The first view, which they refer to as the "romantic" view, is associated with the research of de Soto [1989; 2000]. According to this view, "unofficial firms are potentially extremely productive, and are held back by government taxes and regulation, as well as by lack of secure property rights and access to finance”. ${ }^{15}$ This view is particularly optimistic about informality, and seems to suggest that reducing the burden of taxes and government regulation would lead informal firms to switch into formality and potentially increase the overall productivity of the economy.

The second view is associated with the McKinsey Global Institute reports (summarized by Lewis [2004]). According to this view, informal firms are parasites stealing from fiscal authorities and underperforming. They are the persistently unproductive firms that drain fiscal resources and contribute to the low level of infrastructure. This view emphasizes that informal firms not only hurt the productive sector of the economy by stealing market share from the more productive firms, but they also reduce their own potential by remaining small in order to avoid detection. Under this view, informal firms are reducing the overall performance of the economy. Increasing enforcement to eradicate informal firms would improve the efficiency of the economy.

The third view, which La Porta and Shleifer [2008] refer to as the "dual" view, is associated with the early work of Harris and Todaro [1970] and Rauch [1991]. It emphasizes the inefficiencies of informal firms, which cannot survive except when they are indirectly subsidized

\footnotetext{
${ }^{15}$ La Porta and Shleifer [2008]
} 
by avoiding the taxes and regulations of governments. In this view, increasing the productivity of the overall economy will drive these intrinsically unproductive firms out of business. They cannot compete with formal firms and, as economic development progresses, they will disappear. The policy implications of each polar view are quite different. Under the "romantic view," the appropriate policy would be to reduce the burden of regulation and, as a consequence, the economy should increase its efficiency and overall productivity. The McKinsey view suggests that the appropriate policy is to tax the informal sector and bring it into the fiscal sector by increasing the enforcement and compliance with regulations and taxes. The "dual" view suggests that economic development will inevitably cause the informal firms to go out of business.

All of these interpretations of informality are consistent with the evidence that informal firms are smaller and less productive than formal ones (Maloney [2009], La Porta and Shleifer [2008], Levy [2008]). Moreover, the "dual" view can be expressed as an equilibrium result in a self-selection model that embraces the "romantic" and "McKinsey views". Savard et al. [1997], de Paula and Scheinkman [2008] and Amaral and Quintin [2006] provide three complementary models that lead to equilibrium outcomes characterized by a substantial presence of informal firms that could not survive in the formal sector and that are smaller and less productive than formal firms.

These models share similar features about the way they model how firms decide to become formal. Firms sort into the formal sector based on an underlying distribution of managerial talent. A trade-off is evident as informal firms are able to avoid paying taxes but face an increasing cost of evasion. For instance, in the model of De Paula and Sheinkman (DPS), formal firms have to pay taxes but face a lower price of capital. Informal firms pay a higher price of capital and incur costs of evasion that increase with the size of the firm. These models share the economic intuition that in equilibrium, firms self-select into the formal sector based on the underlying distribution of managerial talent. Here we sketch a simplified version of a prototypical model of self-selection to clarify the discussion of informality.

It is important to note that self-selection in static models implies that the observed differences in productivity between formal and informal firms are the result of a selection process, leaving no place for a causal impact of the formal status on productivity or firms' 
performance. ${ }^{16}$ Informality is a consequence of regulations that reduce the profitability of being formal, not primarily a direct cause of lower productivity.

\section{A. A Model of Self-Selection Without Investment}

We present a simplified version of the model in Savard et al. [1997] and de Paula and Scheinkman [2008]. We seek to capture the nature of self-selection in the firm's decision to join the informal sector. Consider an economy where firms have to decide whether to join the formal sector or not. Let $\theta$ be firm productivity. There is an underlying distribution of firm productivity, $\varphi(\theta)$, and firms face a trade-off because joining the formal sector allows them to sell their product at a higher price, but they would have to pay labor taxes in addition to a higher fixed cost relative to firms in the informal sector. All firms share the same production function, $f(\theta, L)=\theta L^{\alpha}$. Output prices vary with firms' status, $P_{f}>P_{I}$, where $P_{f}$ and $P_{I}$ denote formal and informal prices, respectively. Thus, gross earnings are $P_{i} \theta L^{\alpha}$, for $i \in\{$ formal, informal $\}$. Formal firms pay labor taxes. The cost functions are $\bar{C}_{f}=(1+\tau) w L+c_{f}$ and $\bar{C}_{i}=w L+c_{I}$ for formal and informal firms, respectively, where $c_{f}$ and $c_{I}$ are fixed costs of doing business in each sector. ${ }^{17}$ Here the main assumption is that informal firms avoid paying labor taxes and face a lower fixed cost, but they must sell their product at a lower price. The firm problem is

$$
\max _{\text {formal/informal }}\left\{\max _{L} P_{f} \theta L^{\alpha}-w(1+\tau) L-C_{f} ; \max _{L} P_{I} \theta L^{\alpha}-w L-C_{I}\right\} .
$$

It is straightforward to show that the solution to this problem implies that there is a threshold level of productivity $\hat{\theta}$ such that for firms with high enough productivity, so $\theta>\hat{\theta}$, the firm chooses to be formal and for $\theta<\hat{\theta}$ the firm chooses to be informal. ${ }^{18}$ Graphically, the

\footnotetext{
${ }^{16}$ This result contrasts with the conclusion of Perry et al. [2007]. Those authors study a sample of approximately 5,000 micro-firms and attempt to identify the effect of formality and participation in other societal institutions on firms' performance. They claim to find a positive causal effect of formality (defined as paying at least some taxes, $30 \%$ of the firms in their sample). However, it is unclear that their matching estimator actually corrects the selection bias because they have a limited set of variables to match on. Another limitation of their study is that that the vast majority of the firms in their sample are self-employed workers (i.e. two thirds of the sample).

${ }^{17}$ For simplicity, we assume a fixed cost associated with the firms' status, but the model can easily be extended to incorporate a cost that is increasing in the firms' size, capturing the increasing probability of being caught by government officials.

${ }^{18}$ We can solve for the equilibrium threshold of productivity:
} 
solution of this model implies a cutoff above which firms become formal. Figure 24 plots the profit functions for the same firm operating in the formal and informal sectors ( $\pi_{f}$ and $\pi_{I}$ respectively) as a function of firm productivity.

Figure 24. Equilibrium Level of Profits in the Formal and Informal Sectors

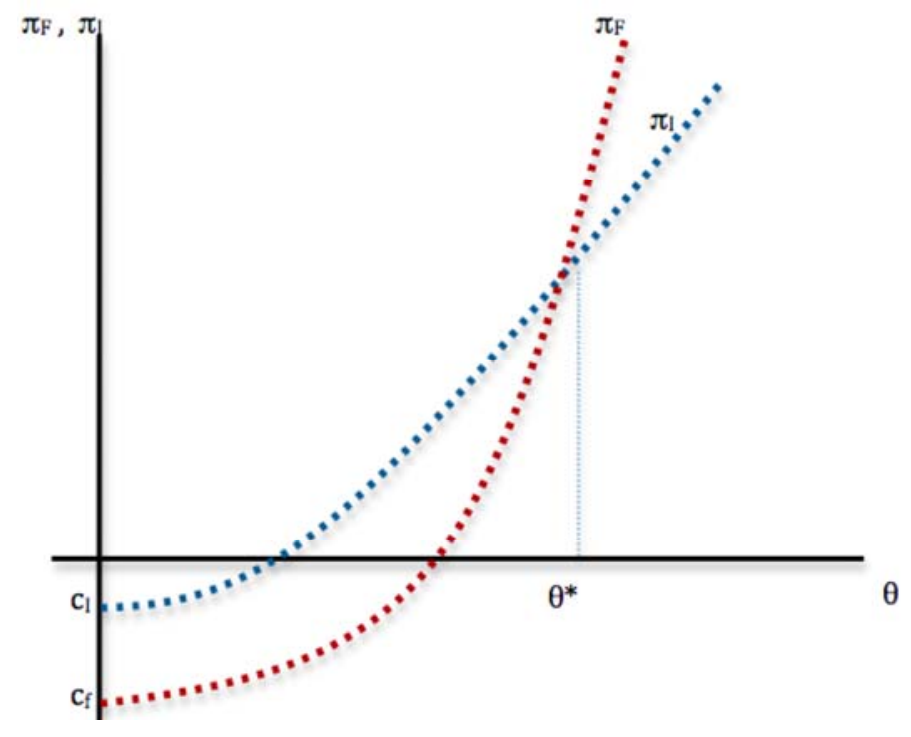

Our view of informality as an outcome of a self-selection process is consistent with all three views of informality summarized in La Porta and Shleifer [2008]. Here, formal firms are more productive through a selection process, and not because informality reduces productivity. Informal firms evade taxes and lower the fiscal base contributing to weak public infrastructure. But notice that contrary to claims by Maloney [2009] and Perry et al. [2007], informality does

(footnote 19 continued)

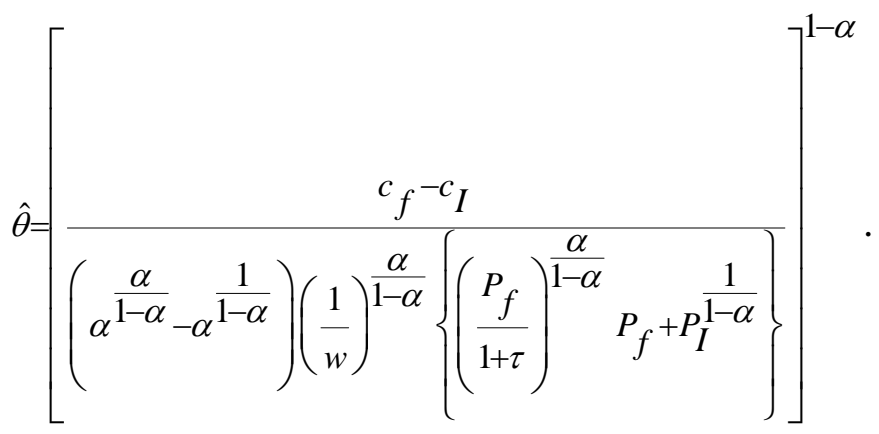


not cause less productivity. Lower productivity firms select into informality. The cause of the selection is the burden of regulation and the greater cost of doing business.

As long as the distribution of talent (or firms' productivity) determines the firms' status and the self-selection criteria, claims about static inefficiencies of informality remain ambiguous. In fact, one can argue that the existence of informal firms, or the informal sectors of formal firms that evade labor regulation, serves a productive role in allowing firms to hire informal workers in response to transitory shocks in demand. In this case, firms would avoid severance costs and other costs of adjustment that are large, partly due to excessive regulation. Moreover, informal firms employ and generate revenues for millions of people who otherwise would not be able to compete in an environment characterized by a high cost of doing business and regulation.

Removing its burden of regulation and taxation, the Mexican economy would attract more firms into formality and raise the public resources to invest in its infrastructure. Raising enforcement and revenue collection on informal firms would operate to drive firms out of the informal sector altogether, with potential negative impacts on unemployment and increases in poverty levels.

The importance of regulation in causing informality cannot be overemphasized. Evidence from Brazil's increase in the cost of labor regulation is informative. The constitutional reform in Brazil implemented in 1988 made it much harder to fire workers. Ulyssea [2010] reports a dramatic increase in the share of labor in the informal sector as a consequence of the increase in regulation. See Figure 25. 
Figure 25. Informal Sector Evolution in Brazil. Source: Monthly Survey (PME). Second yaxis: Informal Salaried Employees as a Share of Total Informal Employment (in \%)

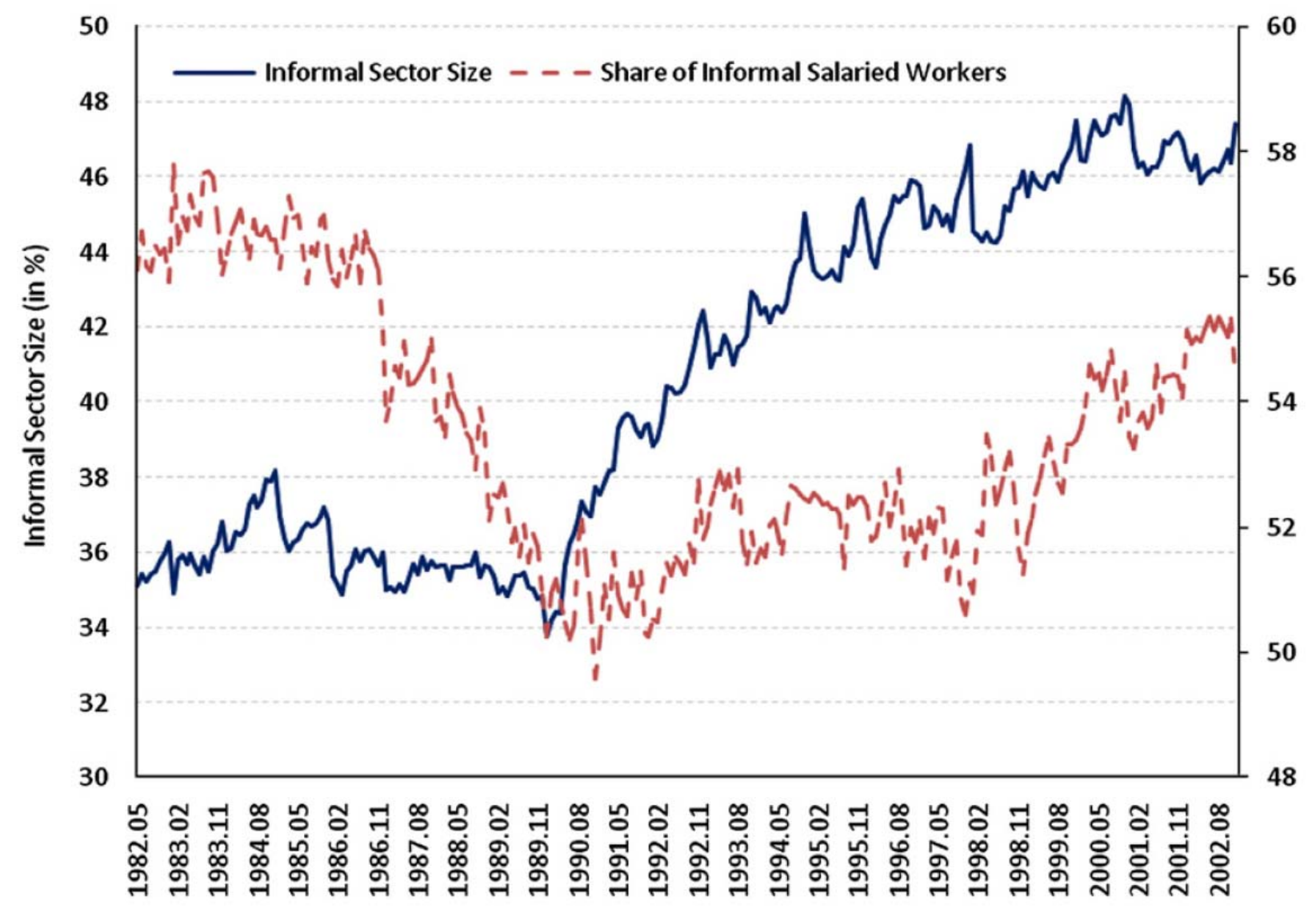

Source: Ulyssea [2010]

\section{B. Dynamic Inefficiencies}

The previous analysis is based on a static model of informality. In that model, regulation selects less productive firms into the informal sector. However, the dynamic implications of informality are likely to be very important. Informality can cause low productivity by affecting investment. Restricted access to capital markets in the informal sector likely reduces both physical capital and human capital accumulation, although much more empirical research remains to be done to solidify this conclusion. Returns to work experience are lower in the informal sector, suggesting that human capital accumulation is impaired by informality. (See Figure 26.) 
Figure 26. Mean returns to experience of salaried workers by formality status

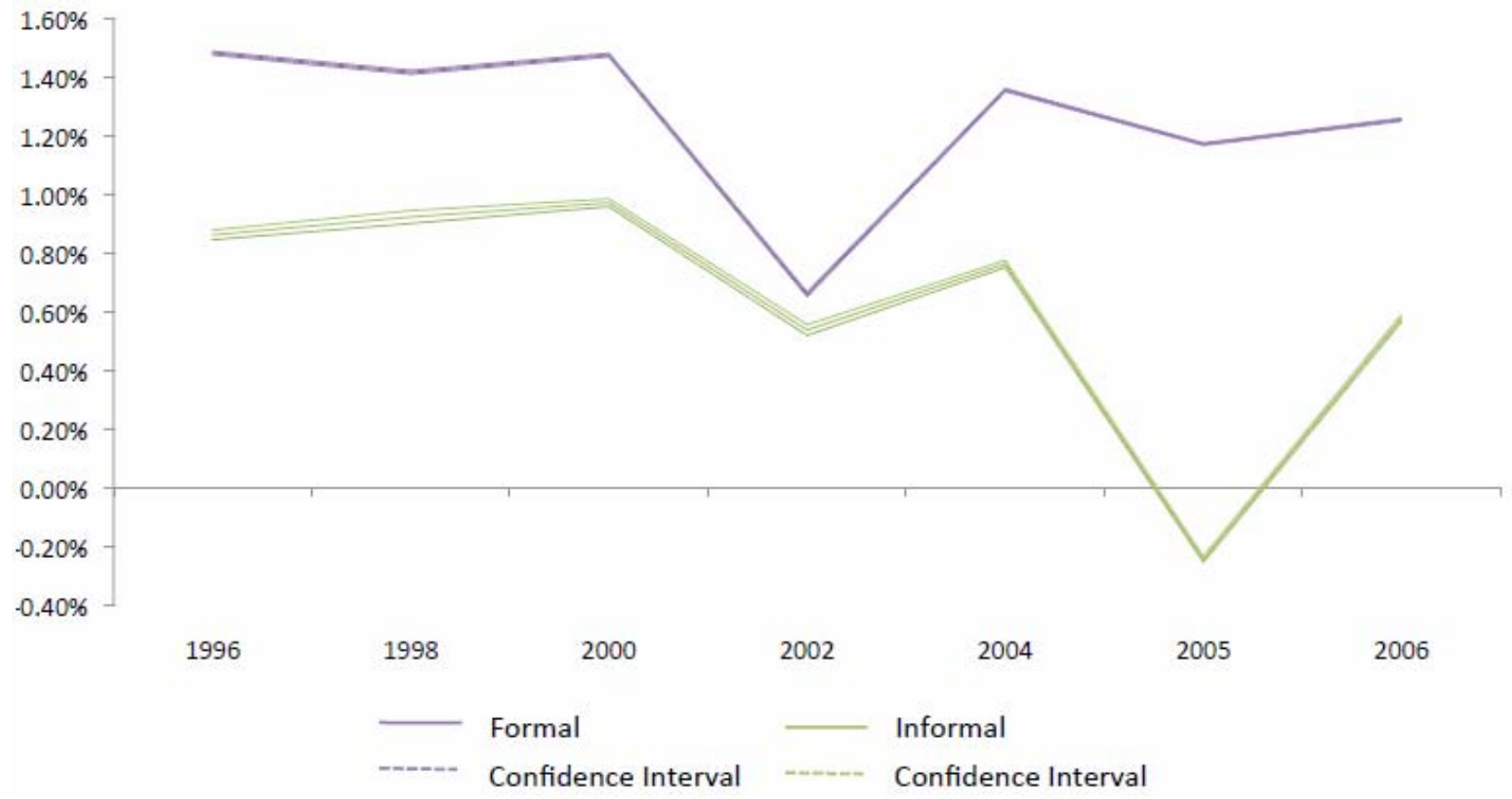

Source: Author's calculations using ENIGH. The retruns to schooling are obtaind from an OLS regression controlling for experience,experience squared, martial status, gender, union status, size of firm and state and industry effects. Formality status is defined as having acces to social secuirty institutions (IMSS, ISSSTE, PEMEX and others). Bounds are obtained with robust standard errors on a 95 percent confidence interval. The effect is estimated at the mean values of experience for each group. 


\section{Informality in Mexico}

Mexican law is not clear on what arrangements should be considered informal. The definitions based on the Mexican Federal Labor Law and the Mexican Law of Social Security are in conflict. The former makes no distinctions among economic activities. Thus, it includes workers in all sectors of the economy, including agriculture. The latter has a special category for agricultural workers. Given these conflicting definitions, any analysis of informality in Mexico should include a discussion of the potential conflict in measurements of informality created by the conflicting provisions of these laws. This discussion is particularly relevant for understanding possible effects of social protection programs in the country which operate in rural and semiurban settings. ${ }^{19}$

Workers and firms in each economic sector face the dichotomy created by the legal framework. Moreover, workers in the agricultural sector are more likely to place higher valuation of the benefits of social protection programs. The reason for this is quite simple: rural villages and municipalities have limited or no access to the bundle of services provided by the formal social security institutions.

Our definitions of informality follow an approach similar to that used by Levy [2008]. He includes agricultural workers in his estimate of illegal poor workers. ${ }^{20}$ Figure 27 shows informal employment decomposed by agriculture and non-agriculture sectors. This graph clearly shows an increase of informality in non-agricultural occupations and a decrease in informality in the agriculture sector. Taking these trends into account, the overall percent of workers not covered by social security has decreased slightly over the period. ${ }^{21}$

${ }^{19}$ We define informality to include the following mutually exclusive categories:

1. Illegal salaried worker: Workers that have a boss and receive a fixed salary on a regular basis and are not covered by any of the social security institutes (IMSS, ISSSTE, PEMEX, and others).

2. Comisionistas: Workers that have a boss but do not receive a salary, they might get paid in tips, per work fees, etc. They are NOT required by law to have social security.

3. Unpaid workers: Those who do not receive monetary payment for their work.

4. Self-employed: Workers with no boss, and work on their own basis.

5. Unclassified Informal: They are employers in firms that are household based. Firms are classified as household based if they do not have a separate accounting for their business. This category also includes a very small number of workers that were not classified in the previous categories, but are included in the informal sector definition of INEGI.

${ }^{20}$ See his Appendix 4.

${ }^{21}$ All our analysis is based on the official labor surveys of INEGI. For the period 1995-2004 we used the Encuesta Nacional de Empleo (ENE) homologated to the Encuesta Nacional de Ocupacion y Empleo (ENOE), and for the 
Figure 27. Informal Employment by relation to Agricultural Sector

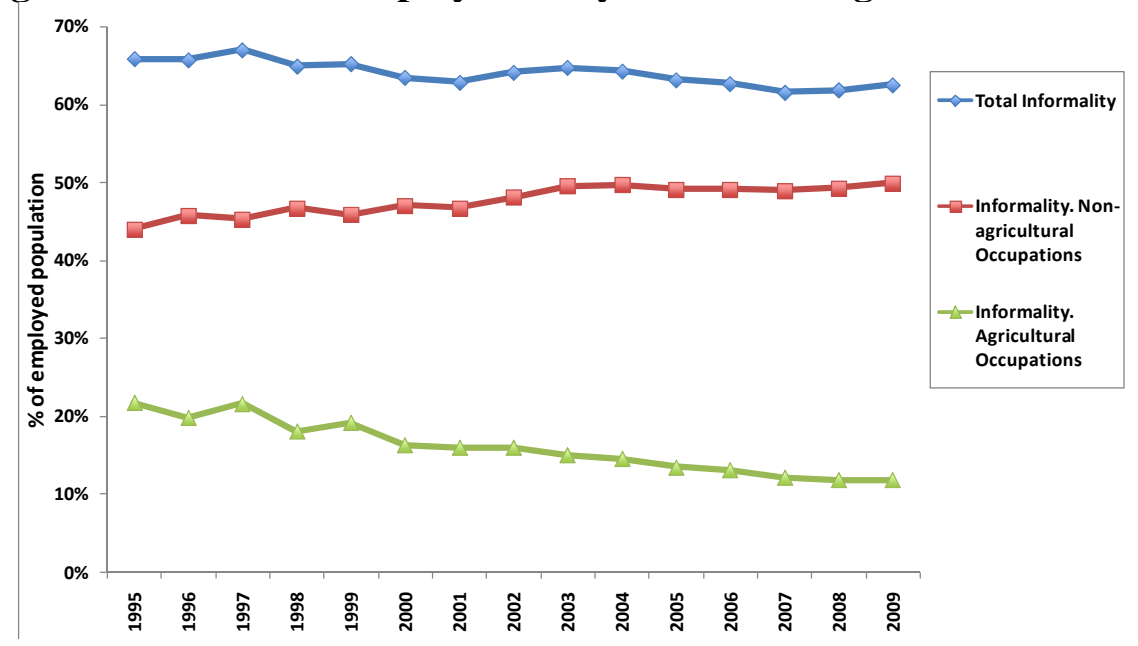

Source: authors' estimation using ENE and ENOE 1995-2009. We used the homologated data publicly available by INEGI

Specifically, the percentage of workers not covered by social security (agriculture and non-agriculture) decreased from 66 to 62 percent between 1995 and 2009. The agricultural workers not covered by social security decreased from 21 to 11 percent, while non-agricultural informality increased from 44 to $50 \%$. The downward trend in agricultural employment and the upward trend in non-agricultural employment are explained by the process of urbanization. The total reduction of agricultural employment was not fully translated into the urban informal labor force. Only half of the population who migrated to urban areas joined the informal economy. In other words, urban areas absorbed the migrant population from the rural areas, both in the formal and informal economy.

Our understanding of informality becomes clearer if we decompose the total economically active population by sector. This allows us to determine how the composition of employment, both formal and informal, is shifting across sectors. Figure 28 describes the changes in the labor force with respect to the economic sector of employment.

period 2005-2009 we used the ENOE. We used only the second quarter of every year. Informality is determined by the status of the interviewee in the week prior to the survey. 


\section{Figure 28. Population Economically Active by Sector of the Economy}

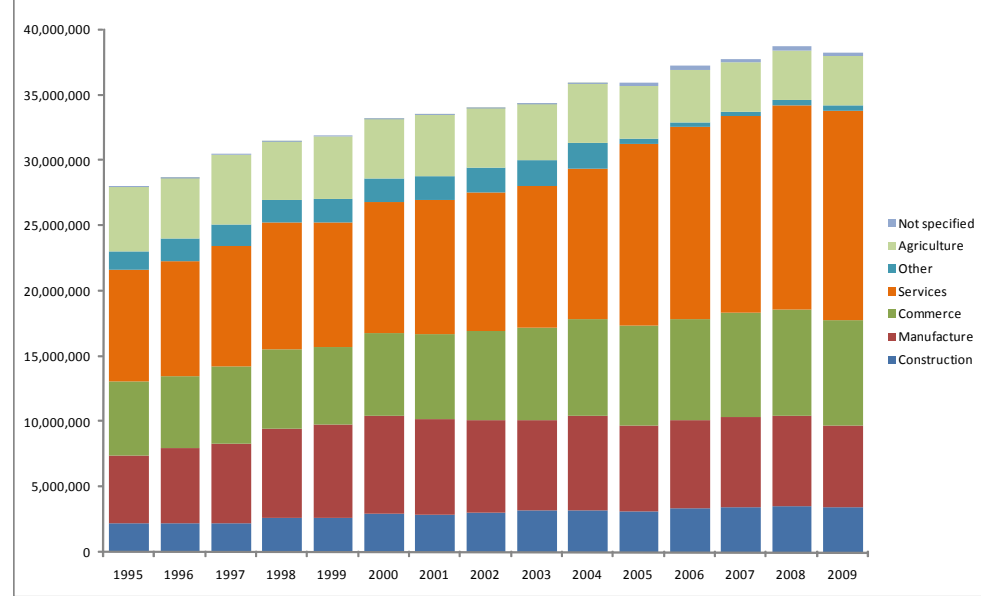

Source: authors' estimation using ENE and ENOE 1995-2009. We used the homologated data publicly available by INEGI

The composition of the Mexican labor force is changing. The labor force is growing in the service and commerce sectors, while the trend is against manufactures and agriculture over the current decade. The transformation of the labor force has an effect on the composition of formal and informal urban labor markets. Growing urbanization is reshaping the composition of the labor markets and is a main cause of the increase in informality.

To get a sense of the elasticity of worker's preferences for social security, we decompose informality into different occupational categories. We study the growth of informality including (Figure 29) and excluding (Figure 30) the agricultural sector.

Figure 29. Composition of Informal Labor Force (1995-2009)

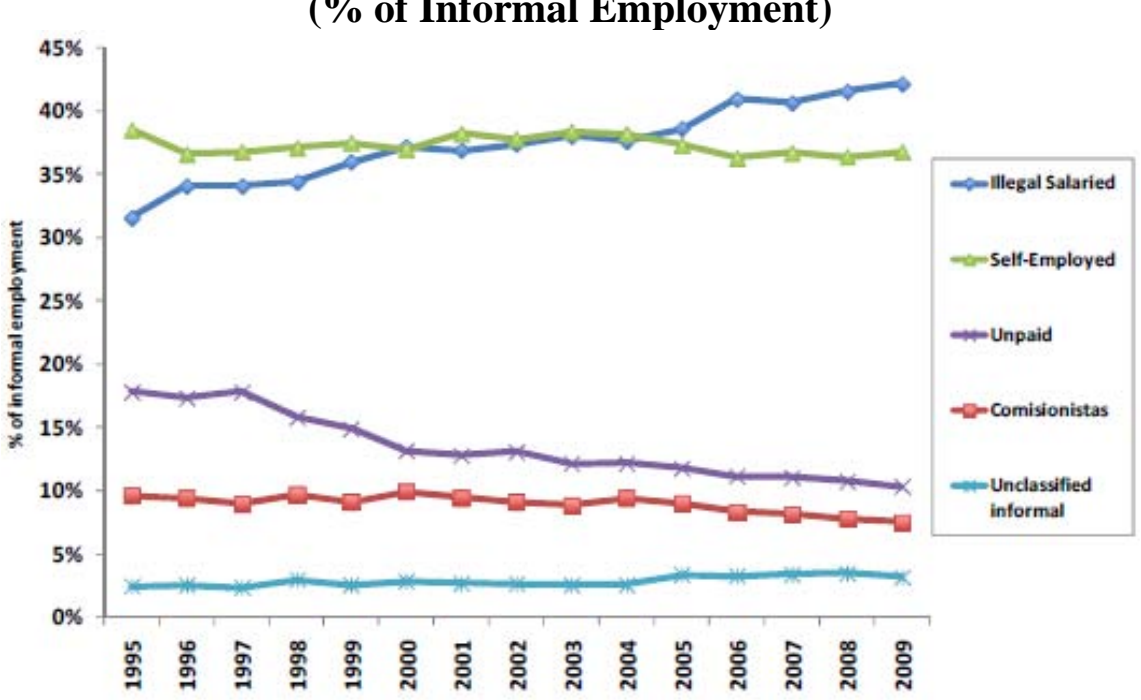

Source: authors' estimation using ENE and ENOE 1995-2009. We used the homologated data publicly available by INEGI 
Figure 30. Composition of Non-Agricultural Informal Labor Force (1995-2009) (\% of Non-Agricultural Informal Employment)

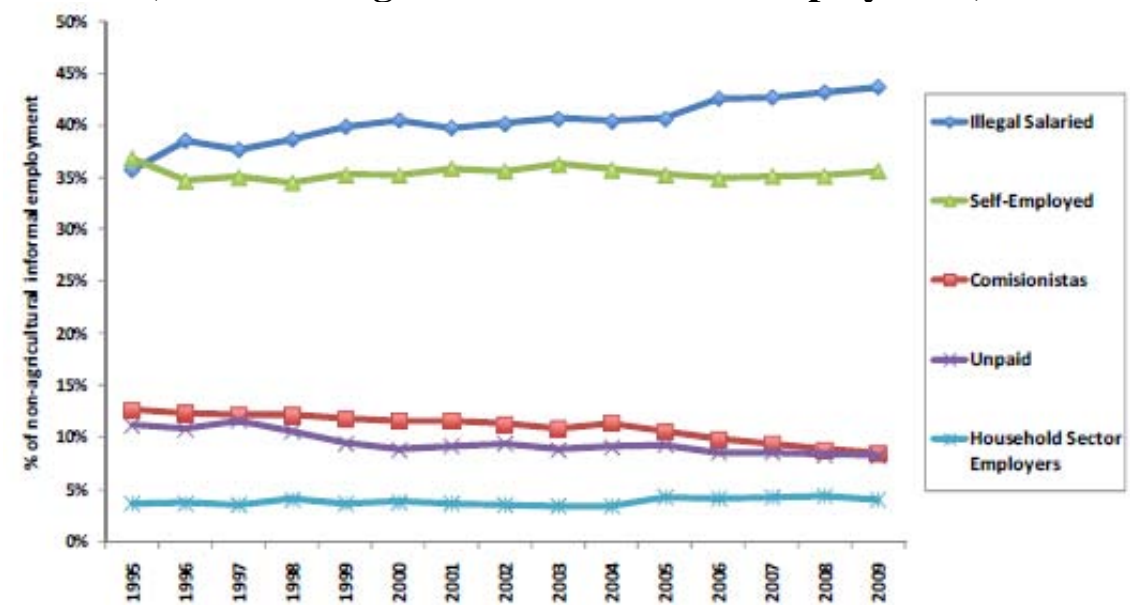

Source: authors' estimation using ENE and ENOE 1995-2009. We used the homologated data publicly available by INEGI

These figures reveal that only the share of the category "illegal salaried workers" has increased over time. This category includes workers who have a boss, receive a salary on a regular basis and are not covered by any of the social security formal institutions (IMSS, ISSSTE, PEMEX). The proportion of self-employed and unclassified informal workers remained stable over the period, while the proportion of comisionistas and unpaid workers decreased over the period. We also analyze the agricultural sector using the same definitions of informal occupations. The trends are quite similar: the category of illegal salaried workers is the only category that increased during the period of analysis, while self-employed, comisionistas and formal salaried remain constant. Only unpaid workers reduced their participation. 
Figure 31. Agricultural employment by type of job

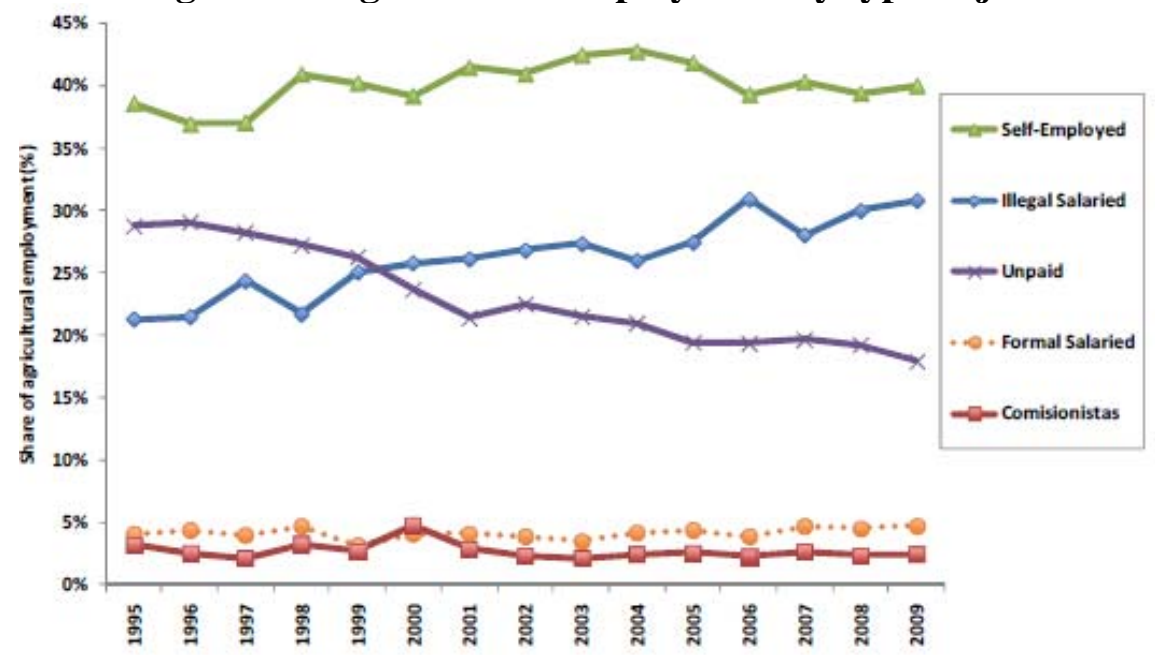

Source: authors' estimation using ENE and ENOE 1995-2009. We used the data publicly available by INEGI

Our analysis of formality and informality is summarized in Figure 32. We observe an increase in the percentage of workers in the formal sector and the illegal salaried workers. The percentage of workers in the formal sector went up from 30 to 35 while the share of illegal salaried workers increased from 20 to 26 percent. Unpaid workers decreased from 12 to 6 percent, while the remaining categories (self-employed, comisionistas and unclassified informal workers) have maintained their participation in the labor force stable.

Figure 32. Total Employment by type of Occupation

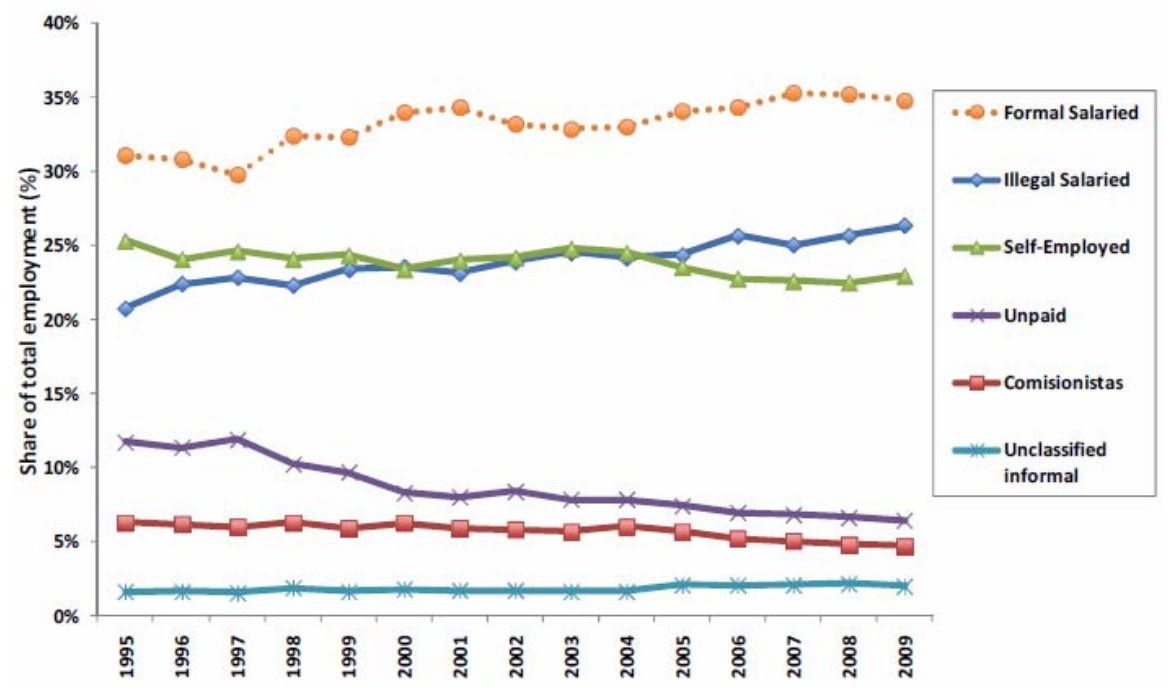

Source: authors' estimation using ENE and ENOE 1995-2009. We used the homologated data publicly available by INEGI 


\section{Seguro Popular and the Growth of Informality}

In 2002, the Mexican federal government introduced Seguro Popular, an ambitious social program whose objective is to provide those individuals (and their families) not covered by social security with a basic health insurance package. Individuals in the formal sector have these benefits. In the informal sector they do not. The Seguro package includes 266 medical interventions, which go from routine check-ups to third level surgeries, and the program is scheduled to cover all uninsured, which in Mexico represent roughly half of the population, by 2013. The percentage of families covered by Seguro Popular is large (Figure 33), varies by region, and has been increasing (Figure 34).

Figure 33. Seguro Popular. Percentage of Families Covered by State in 2009

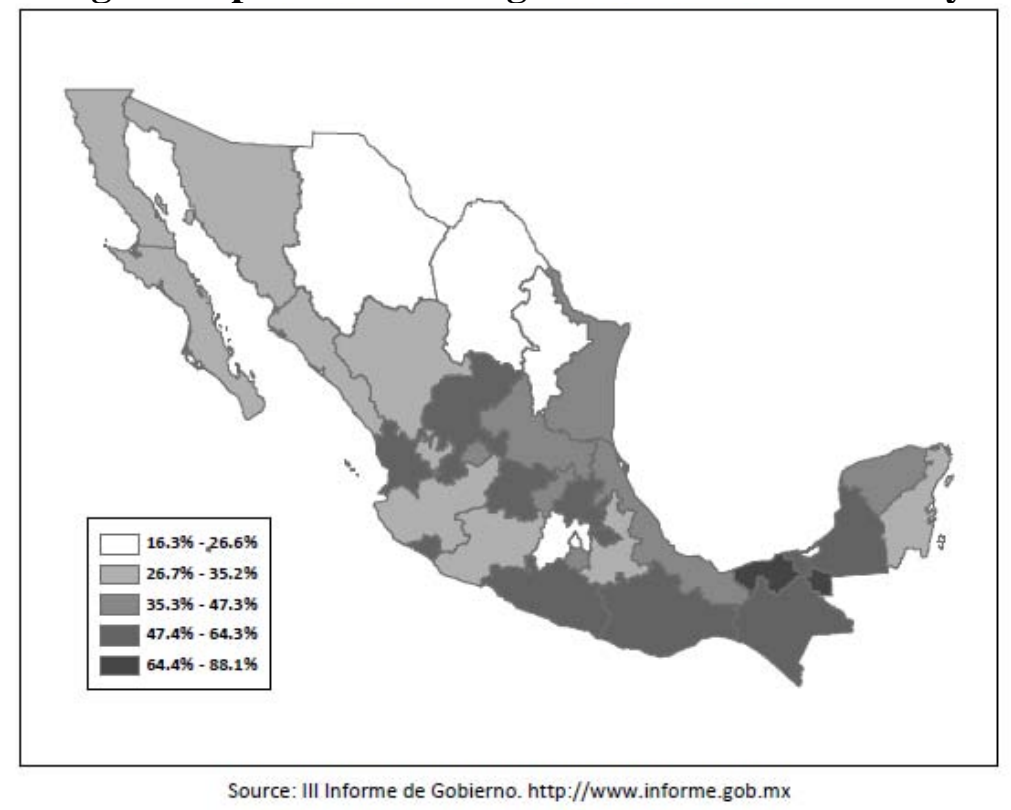

Concerns have been expressed that the way Seguro Popular targets informal workers creates perverse incentives that encourage a decrease in labor supply, or a shift towards working in informal activities, hindering economic growth (Levy [2008]). 
Figure 34. Seguro Popular. Total Households Covered by Year (Millions)

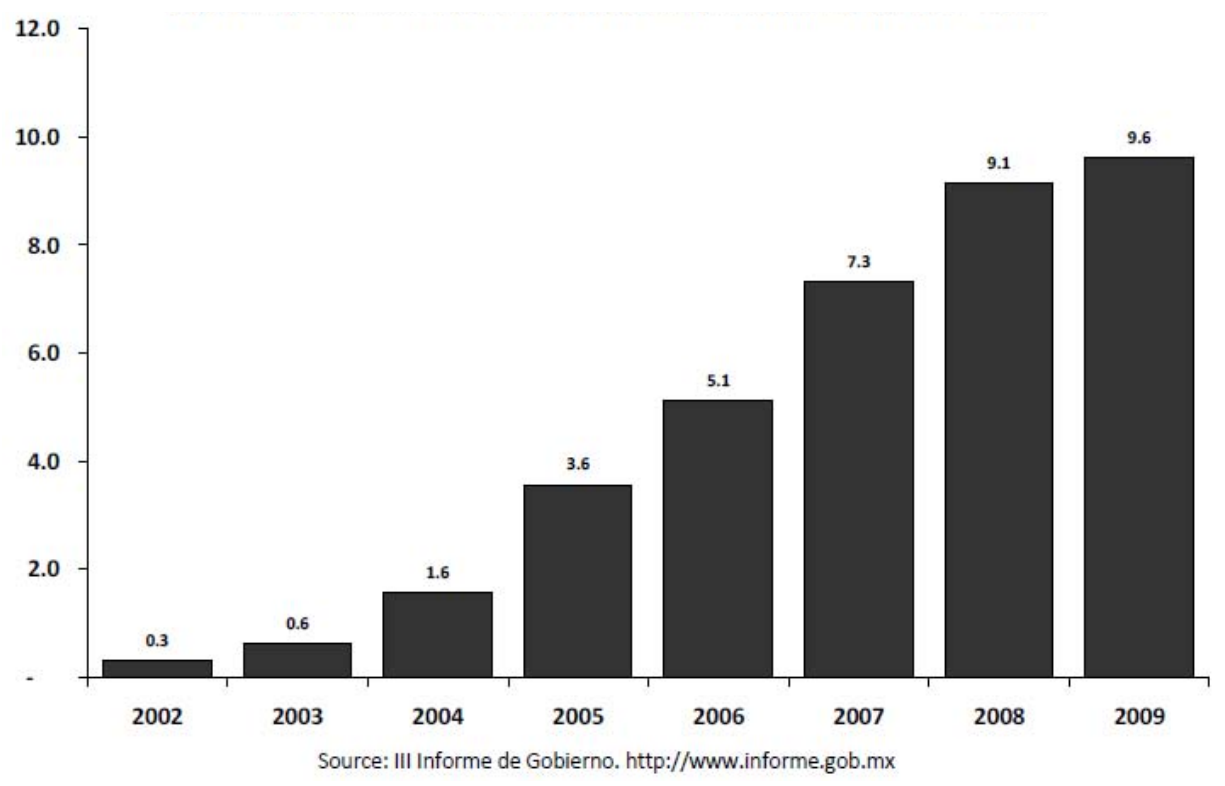

Affiliation with Seguro Popular is reserved for people who are not beneficiaries of Mexico’s social security institutions, either because they are informal workers or because they do not work. Annual fees depend on declared income, but individuals in the lowest two deciles of the income distribution do not have to pay them, and declared income is seldom verified by program administrators. In monetary terms, the benefits provided by the program represent a nontrivial share of the average annual earnings of a salaried worker. See Figure 35.

Figure 35. Seguro Popular. Share of salaried workers’ Annual Earnings

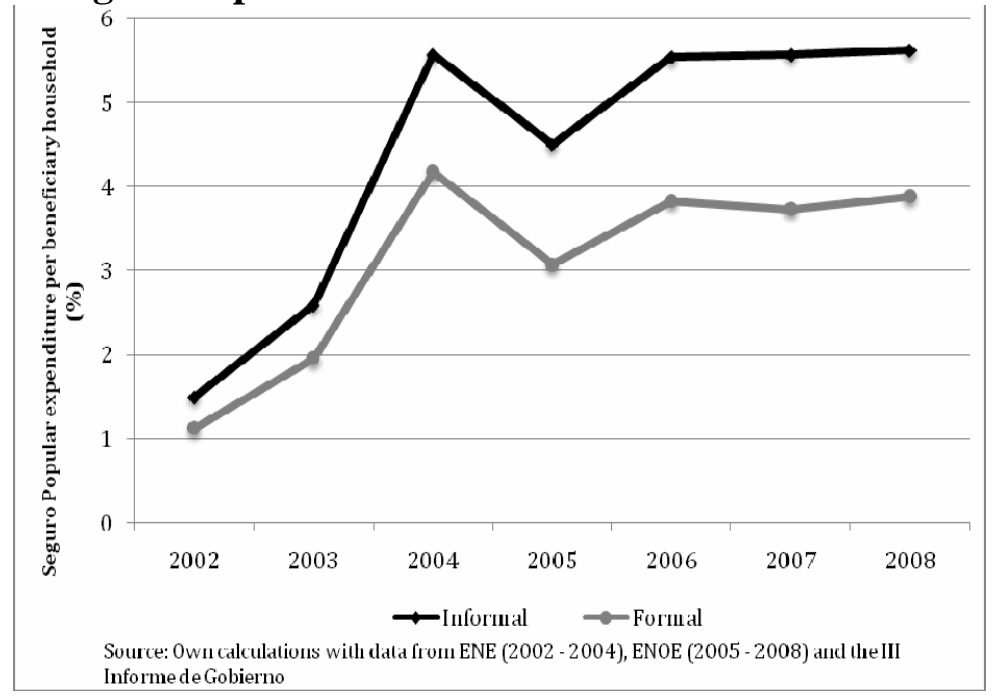


We seek to investigate the effects of expansion of social protection programs such as Seguro Popular as determinants of the trends in informality. A relevant aspect of this analysis is that workers' decisions to participate in the formal sector are based in part on their valuation of social security benefits. Levy [2008] analyzes the effect of social protection programs and social security on the composition of the labor force. According to his argument, those workers who prefer social protection programs are more likely to be employed in any of the following categories of informality: self-employed, unpaid, “comisionistas”, or illegal salaried. The reasoning is that the only requirement for receiving social protection is exclusion from social security, so workers would prefer to have an occupation with a higher wage paid in cash with no social security benefits than a lower wage with contributions to social security.

In our analysis, we explore whether Seguro Popular has had an effect on the level of illegal salaried employment. This category should be covered by social security according to the Federal Law of Labor and the Law of Social Security (there is no legal contradiction for its coverage) and it is the only component that increased over the period.

Figure 36. Trends in illegal salaried employment, external sector and Seguro Popular

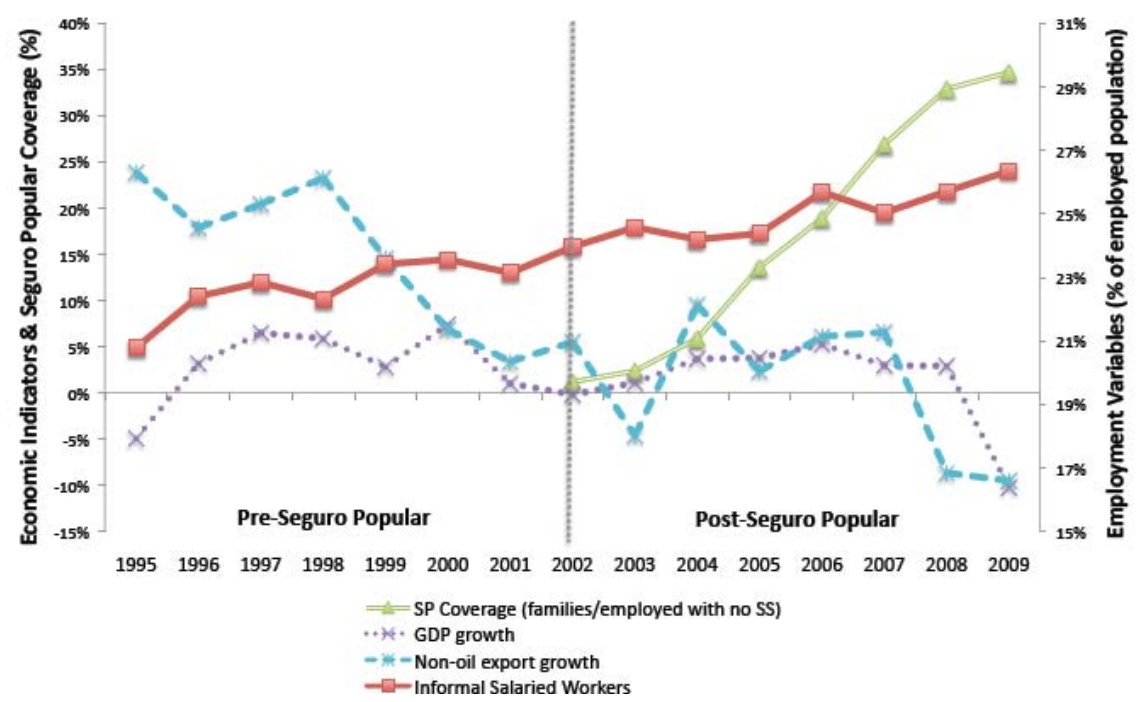

Source: authors' estimation using ENE and ENOE 1995-2009. We used the homologated data publicly available by INEGI

As can be seen from Figure 36, the percentage of illegal salaried workers follows an upward trend even in the years prior to the beginning of Seguro Popular and there is little evidence that Seguro Popular budged the trend line. Furthermore, when comparing other economic indicators before and after the inclusion of the program, the economy experienced 
changes that could also explain the increase in illegal salaried workers. In particular, the growth in exports outside of the oil sector was negative. Since non-oil exports have a direct effect on the employment in the manufacturing sector, the reduction would suggest that the rigidities of key sectors discussed in the first part of the paper have a substantial impact on the trend of informality. The explanation of this would be the lower attractiveness of doing business in Mexico compared with other emerging economies.

Recent research questions the claim that Seguro Popular fostered informality. Barros [2009] uses individual data from the National Survey of Households' Income and Expenditure (Encuesta Nacional de Ingreso y Gasto de los Hogares) (ENIGH). He finds no effect of the program on labor force participation nor on the hours worked of beneficiaries. According to his results, Seguro Popular does not shift formal workers to the informal sector. Knox [2008] uses individual data from the Evaluation Survey of Urban Households (Encuesta de Evaluación de los Hogares Urbanos) (ENCELURB) and municipio-level data from the National Employment Survey (EncuestaNacional de Empleo) (ENE). He finds no statistically significant effect of the program on formal employment rates. Knox [2008] uses individual data from ENCELURB, and finds no effects on labor force participation, hours worked nor weeks worked of all heads of household.

If the program has shifted a relevant number of workers from formal to informal activities, we should observe a fall in formal employment with a corresponding increase in the wages of formal workers, as well as an increase in informal employment, accompanied by a fall in informal workers' wages. However, as previously established, employment in both formal and informal activities has risen and, as Figure 37 shows, real wages for both types of workers have increased. 
Figure 37. Salaried Workers’ Hourly Wages

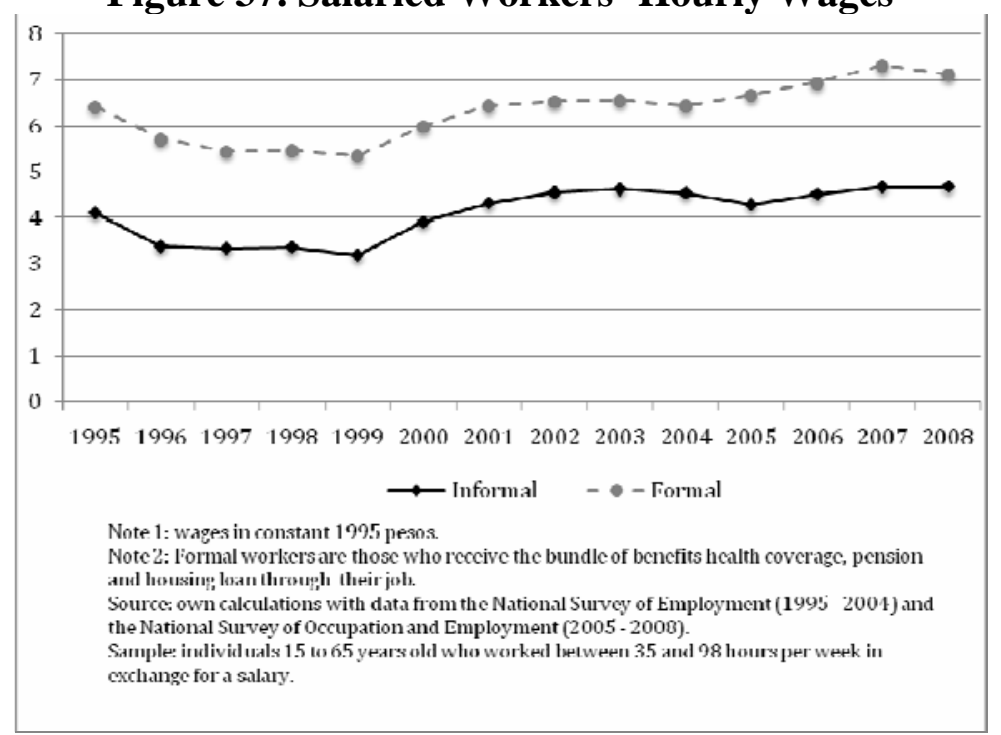

Although the benefits from the program in monetary terms are apparently large, they might not significantly affect working decisions. Although Seguro Popular covers a wide array of medical interventions, a worker who moved from formal to informal activities would forego not only medical benefits, but also access to housing loans, a pension, disability insurance and other benefits. Moreover, as is well-documented in the literature and evident in Figure 37, average wages are higher for formal workers (Moreno [2007], Esquivel and Ordaz-Diaz [2008]).

A model with free mobility of labor between activities, driven by an implicit assumption of homogeneous agents, would predict a large shift of workers from formal to informal activities as a result of an increase in the benefits of performing the latter. There is little evidence of such a shift.

Recent empirical studies show high and symmetric mobility of individuals between informal and formal activities, with higher mobility between formal and informal activities among low-wage earners than among high-wage earners, and with higher search for jobs in and entry into informality during upturns than downturns. These studies have been interpreted as evidence of close integration of formal and informal markets (Levy [2008], Maloney [1999], Maloney [2009]) and have been used to justify assumptions of homogeneity and free mobility. In fact, this evidence is consistent with segmentation.

First, as noted by Dickens and Lang [1992], lack of mobility should not be confounded with barriers to entry, because in the extreme no mobility between sectors could be consistent with complete barriers to entry or no barriers at all. For example, if workers always enter their 
preferred sector on their first job, we would not observe mobility between sectors even in the absence of barriers. Second, if highly productive individuals can perform whatever activity they prefer, but less productive workers must queue for formal jobs, then less productive workers will be more likely to move into formality.

Finally and more importantly, the idea that in a segmented labor market flows from formality into informality should only occur during bad economic times, as individuals "seek some form of income to stay afloat” (Maloney [2009]), comes from a traditional view of labor market segmentation as a situation where some individuals who would otherwise optimally choose to be formal workers, are prevented from doing so by institutional barriers to occupational mobility and, therefore, must queue for formal jobs and work in informal activities only to subsist while they obtain one. Related to this view is the incorrect notion that, in a competitive market, all workers should be indifferent between working in formal or informal activities in equilibrium.

As Magnac [1991] points out, even if the market is competitive as a whole, comparative advantages remain for almost all workers, and thus it is important to distinguish between marginal and average agents. Segmentation does not necessarily imply that those individuals who are observed performing informal activities are forced to do so. Rationing can simply mean that, on top of the foregone earnings, there is a direct cost of entry into formality, which will be paid for by those who find it in their best interest to do so. Whether there is free entry into the regulated sector or not, comparative advantages exist and dictate choices. Flows from formality into informality might occur during upturns even in the presence of segmentation.

Accounting for comparative advantage in the labor market makes it less likely that Seguro Popular massively shifted individuals from formality into informality in comparison with a model with homogeneous skills. If comparative advantage dictates choice, as one would expect, because of heterogeneity among individuals, then labor supply between sectors is not completely elastic, whether or not there are or not barriers to entry, and workers will not necessarily change status in response to movements in relative benefits (Marrufo [2001]), particularly if the change in the latter were perceived to be small. Using data from the Social Security Reform of 1997, Marrufo [2001] estimates a pass-through in the covered sector of taxes to wages of $43 \%$ of the tax change, holding benefits constant, and a pass-through of benefits to wages of $57 \%$ of the value of the former, assuming taxes are unchanged and benefits are fully 
valued by workers. These estimates imply that labor supply is neither completely inelastic nor completely elastic, a view consistent with the notion that Seguro Popular has not significantly altered decisions regarding workers' formal status.

Knox [2008] shows that there is no statistically significant link between the implementation of Seguro Popular, and a change in informal employment. Azuara and Marinescu [2010] report similar results from a study of the effect of SP on informality by region that exploits the differences in the introduction of SP across regions. More work remains to be done regarding the impact of social programs on labor outcomes. Given the large expenditure of public resources on social protection programs - around 2 percent of the GDP in 2008 - and the targeted nature of the social protection programs, it is unlikely that they have had no effect on individual working decisions. At issue is the economic importance of this effect. Future research would benefit from explicitly considering and modeling how the incentives of different types of workers, both within the formal and informal statuses, are affected by the changes in relative benefits introduced by social programs. But the available evidence suggests that regulation and not social programs are the principal cause of informality in the Mexican economy. 


\section{Summary}

The Mexican economy has performed poorly over the last 30 years. Monopoly, regulation, taxation and the poor quality of infrastructure and public services explain much of this poor performance. These issues are much discussed but little acted on in Mexican public policy.

We have discussed two additional topics not usually mentioned in discussions of Mexican productivity and economic growth that deserve much greater attention. First, we show that there is an increasing proportion of children living in disadvantaged environments due to changing family structures. Such arrangements lead to less investment in children. This phenomenon will have major implications for child development and the productivity of the work force of the next generation. Progresa/Oportunidades operates too late in the life cycles of disadvantaged children to be effective. Mexican policy should better target the early preschool years of disadvantaged children.

Second, we have addressed the problem of informality in the Mexican economy. The major cause of informality is regulation and taxation. Regulation causes less productive firms to participate in the informal sector to avoid costs. This has dynamic effects on investment in physical and human capital, and reduces productivity growth in Mexico. There is little evidence that the introduction of social programs targeted towards informal workers has played a major role in promoting informality. 


\section{References}

Amaral, Pedro S. and Quintin, Erwan (2006). "A Competitive Model of the Informal Sector." Journal of Monetary Economics 53(7): 1541-1553.

Azuara, Oliver and Marinescu, Ioanna (2010). "Informality and the Expansion of Social Protection Programs: The Case of Mexico." Unpublished manuscript, University of Chicago.

Baez, Gabriela (2006). Communications Markets in Mexico: Premium Country Report, 2006 Edition. Cambridge, MA, Pyramid Research.

Barros, Rodrigo (2009). "Wealthier but Not Much Healthier: Effects of a Major Health Insurance Program for the Poor in Mexico." Stanford University

Behrman, Jere R., Parker, Susan W. and Todd, Petra E. (2006). "Long-Term Impacts of the Oportunidades Conditional Cash Transfer Program on Rural Youth in Mexico." in Poverty, Inequality, and Policy in Latin America. S. Klasen, ed. Cambridge, MA, MIT Press.

Behrman, Jere R., Sengupta, Piyali and Todd, Petra E. (2000). "The Impact of Progresa on Achievement Test Scores in the First Year." International Food Policy Research Institute,

Borghans, Lex, Duckworth, Angela L., Heckman, James J. and ter Weel, Bas (2008). "The Economics and Psychology of Personality Traits." Journal of Human Resources 43(4): 972-1059.

Boucher, Stephen R. , Stark, Oded and Taylor, J. Edward (2005). "A Gain with a Drain? Evidence from Rural Mexico on the New Economics of the Brain Drain." Department of Agricultural and Resource Economics, University of California at Davis Working Paper, 05-005.

Buvinic, Mayra (2000). "Costos De La Maternidad Adolescente En Barbados, Chile, Guatemala Y México." in Familia, Género Y Pobreza. M. Paz López and V. Salles, eds. Porrúa, Grupo interdisciplinario sobre Mujer, Trabajo y Pobreza.

Carneiro, Pedro and Heckman, James J. (2003). "Human Capital Policy." in Inequality in America: What Role for Human Capital Policies? J. J. Heckman, A. B. Krueger and B. M. Friedman, eds. Cambridge, MA, MIT Press: 77-239.

Chiquar, Daniel and Ramos-Francia, Manuel (2009). "Competitiveness and Growth of the Mexican Economy." Banco de Mexico Working Papers Series, No. 2009-11.

Coleman, James S. (1966). Equality of Educational Opportunity. Washington, DC, U.S. Dept. of Health, Education, and Welfare, Office of Education.

Comisión Federal de Competencia (2004). La Competencia Económica En México. México City, CFC.

Cortes, Fernando (1997). "Determinantes De La Pobreza De Los Hogares. Mexico, 1992." Revista Mexicana de Sociología 59(2): 131-160.

Cortés, Fernando and Rubalcava, Rosa M. (1995). El Ingreso De Los Hogares. Vol. 7. Mexico City, Instituto Nacional de Estadística, Geografía e Informática.

Cunha, Flavio and Heckman, James J. (2006). "Investing in Our Young People." Unpublished manuscript, University of Chicago, Department of Economics.

Cunha, Flavio and Heckman, James J. (2007). "The Technology of Skill Formation." American Economic Review 97(2): 31-47. 
Cunha, Flavio and Heckman, James J. (2008). "Formulating, Identifying and Estimating the Technology of Cognitive and Noncognitive Skill Formation." Journal of Human Resources 43(4): 738-782.

Cunha, Flavio and Heckman, James J. (2009). "The Economics and Psychology of Inequality and Human Development." Journal of the European Economic Association 7(2-3): 320364.

Cunha, Flavio, Heckman, James J., Lochner, Lance J. and Masterov, Dimitriy V. (2006). "Interpreting the Evidence on Life Cycle Skill Formation." in Handbook of the Economics of Education. E. A. Hanushek and F. Welch, eds. Amsterdam, North-Holland: 697-812.

De Buen Lozano, Nestor and De Buen Unna, Carlos E. (2001). Estudio Del Mercado De Trabajo De Mexico: El Marco Normativo E Institucional. Propuestas Para Incrementar La Flexibilidad Laboral. Washington, DC, World Bank.

de Paula, Aureo and Scheinkman, José A. (2008). "The Informal Sector."

de Soto, Hernando (1989). The Other Path: The Invisible Revolution in the Third Worlds. New York, Harper and Row Publishers.

de Soto, Hernando (2000). The Mystery of Capital. Why Capitalism Triumphs in the West and Fails Everywhere Else. New York, Basic Books.

Dickens, William T. and Lang, Kevin (1992). "Labor Market Segmentation Theory: Reconsidering the Evidence." NBER Working Paper No. 4087.

Esquivel, Gerardo and Ordaz-Diaz, Juan Luis (2008). "¿Es La Política Social Una Causa De La Informalidad En México?" Ensayos 27(1): 1 - 32.

Fernald, Lia C., Gertler, Paul J. and Neufeld, Lynnette M. (2009). "10-Year Effect of Oportunidades, Mexico's Conditional Cash Transfer Programme, on Child Growth, Cognition, Language, and Behaviour: A Longitudinal Follow-up Study." The Lancet 374(9706): 1997-2005.

García-Verdú, Rodrigo (2007). "Demographics, Human Capital and Economic Growth in Mexico: 1950-2005." Working paper, The World Bank, Washigton D.C. .

García, Brígida and Rojas, Olga (2002). "Cambios En La Formación Y Disolución De Las Uniones En América Latina." Gaceta Laboral 8(3): 391-410.

García, Brígida and Rojas, Olga (2001). "Recent Transformations in Latin American Families: A Sociodemographic Perspective." XXIV General Population Conference of IUSSP.

Gertler, Paul J. and Fernald, Lia C. (2004). "The Medium Term Impact of Oportunidades on Child Development in Rural Areas." Unpublished manuscript, University of California at Berkeley.

Giorguli Saucedo, Silvia E. (2002). "Estructuras Familiares Y Oportunidades Educativas De Los Niños Y Niñas En México." Estudios Demográficos y Urbanos 51: 523-546.

Gluckman, Peter D. and Hanson, Mark A. (2005). The Fetal Matrix: Evolution, Development, and Disease. Cambridge, UK, Cambridge University Press.

Hanson, Gordon H. and Woodruff, Christopher (2003). "Emigration and Educational Attainment in Mexico."

Harris, John R and Todaro, Michael P (1970). "Migration, Unemployment \& Development: A Two-Sector Analysis." American Economic Review 60(1): 126-142.

Heckman, James J. (2006). "Skill Formation and the Economics of Investing in Disadvantaged Children." Science 312(5782): 1900-1902.

Heckman, James J. (2008). "Schools, Skills and Synapses." Economic Inquiry 46(3): 289-324. 
Heckman, James J., Malofeeva, Lena, Pinto, Rodrigo and Savelyev, Peter A. (2010a). "Understanding the Mechanisms through Which an Influential Early Childhood Program Boosted Adult Outcomes." Unpublished manuscript, University of Chicago, Department of Economics.

Heckman, James J., Moon, Seong Hyeok, Pinto, Rodrigo, Savelyev, Peter A. and Yavitz, Adam Q. (2010b). "A Reanalysis of the High/Scope Perry Preschool Program." Unpublished manuscript, University of Chicago, Department of Economics. First draft, September, 2006.

Heckman, James J., Stixrud, Jora and Urzua, Sergio (2006). "The Effects of Cognitive and Noncognitive Abilities on Labor Market." Journal of Labor Economics 24(3): 411.

Hernadez-Leon, Ruben and Zúñiga, Victor, Eds. (2006). New Destinations: Mexican Immigration in the United States. New York, Russell Sage Foundation.

Knox, Melissa (2008). "Health Insurance for All: An Evaluation of Mexico's Seguro Popular Program." Unpublished manuscript, Department of Economics, University of California Berkley.

La Porta, Rafael and Shleifer, Andrei (2008). "The Unofficial Economy and Economic Development." Brookings Papers on Economic Activity, Fall.

Levy, Santiago (2008). Good Intentions, Bad Outcomes: Social Policy, Informality and Economic Growth in Mexico. Washington, D.C., The Brookings Institute.

Levy, Santiago and Walton, Michael (2009). No Growth without Equity?: Inequality, Interests, and Competition in Mexico. Washington, D.C., World Bank Publications.

Lewis, William W. (2004). The Power of Productivity: Wealth, Poverty, and the Threat to Global Stability. Chicago, University of Chicago Press.

Lien, Nguyen My, Meyer, Knarig Katchadurian and Winick, Myron (October, 1977). "Early Malnutrition And "Late" Adoption: A Study of Their Effects on the Development of Korean Orphans Adopted into American Families." American Journal of Clinical Nutrition 30: 1734-1739.

Magnac, Thierry (1991). "Segmented or Competitive Labour Markets." Econometrica 59(1): 165-187.

Maloney, William F. (1999). "Does Informality Imply Segmentation in Urban Labor Markets? Evidence from Sectoral Transitions in Mexico." World Bank Economic Review 13(2): 275-302.

Maloney, William F. (2009). "Mexican Labor Markets: Protection, Productivity, and Power." in No Growth without Equity? Inequality, Interests, and Competition in Mexico. S. Levy and M. Walton, eds. Washington, D.C., The World Bank.

Marrufo, Grecia (2001). "The Incidence of Social Security Regulation: Evidence from the Reform in Mexico." Thesis, Department of Economics, University of Chicago.

Mayer-Serra, Carlos Elizondo (2009). "Perverse Equilibria: Unsuitable but Durable Institutions." in No Growth without Equity? Inequality, Interests, and Competition in Mexico. S. Levy and M. Walton, eds. Washington, DC, The World Bank: 157-202.

McKenzie, David and Hildebrandt, Nicole (2005). "The Effects of Migration on Child Health in Mexico." Economia 6(1): 257-289.

McKenzie, David and Rapoport, Hillel (2006). "Can Migration Reduce Educational Attainment? Evidence from Mexico." The World Bank Policy Research Working Paper, 3952.

McLanahan, Sara (2004). "Diverging Destinies: How Children Are Faring under the Second Demographic Transition." Demography 41(4): 607-627. 
McLanahan, Sara (2009). "Fragile Families and the Reproduction of Poverty." The Annals of the American Academy of Political and Social Science 621(1): 111-131.

Meza González, Liliana and Pederzini Villarreal, Carla (2009). "Migración Internacional Y Escolaridad Como Medios Alternativos De Movilidad Social: El Caso De México." Estudios Economicos Numero Extraordinario: 163-206.

Moon, Seong Hyeok (2009). "Skill Formation Technology and Multi-Dimensional Parental Investment." Thesis, University of Chicago.

Moon, Seong Hyeok (2010). "Skill Formation Technology and Multi-Dimensional Parental Investment." Thesis, University of Chicago.

Mora Rivera, José Jorge (2007). "Essays on Migration and Development in Rural México." Thesis, El Colegio de Mexico.

Moreno, Jorge O. (2007). "Are Formal and Informal Labor Market Wages Different? Analyzing the Gains and Losses from Formalization in Mexico." Ensayos 24(1): 1-44.

Organisation for Economic Co-operation and Development (2009). Education at a Glance 2009: Oecd Indicators. Paris, France, OECD Publishing.

Organization for Economic Co-operation and Development (2009). Oecd Economic Surveys: Mexico. Paris, France, Organization for Economic Co-operation and Development.

Parker, Susan W. and Gómez de León, José (2000). "Bienestar Y Jefatura Femenina En Los Hogares Mexicanos." in Familia, Genero Y Pobreza M. de la Paz Lopez and V. Salles, eds. Porrúa, México.

Pérez, A.J. (2008). "Análisis Multiestado Multivariado De La Formación Y Disolución De Las Parejas Conyugales En México." Estudios Demográficos y Urbanos 23(3): 481-511.

Perry, Guillermo, E., Arias, Omar and Fajnzylber, Pablo (2007). Informality: Exit and Exclusion: Building Effective and Legitimate Institutions. Washington, D.C., World Bank Publications.

Quilodrán, Julieta (2000). "Atisbos De Cambios En La Formación De Las Parejas Conyugales a Fines Del Milenio." Papeles de Población 25(July-September): 9-33.

Rauch, J. E. (1991). "On the Size Distribution of Business Firms." Bell Journal of Economics 9(2): 508-523.

Rutter, Michael (2006). Genes and Behavior: Nature--Nurture Interplay Explained. Oxford, UK, Blackwell Publishers.

Rutter, Michael and O'Connor, Thomas G. (2004). "Are There Biological Programming Effects for Psychological Development? Findings from a Study of Romanian Adoptees." Developmental Psychology 40(1): 81-94.

Savard, Luc, Marceau, Nicolas and Fortin, Bernard (1997). "Taxation, Wage Controls and the Informal Sector." Journal of Public Economics 66(2): 293-312.

Solís, P. and Medina, M.E. (1996). " El Efecto De La Fecundidad Sobre La Disolución De Uniones De Mexico." Sociológica 11(32): 79-94.

Ulyssea, Gabriel (2010). "Regulation of Entry, Labor Market Institutions and the Informal Sector." Journal of Development Economics 91(1): 87-99.

Villarreal, Andrés and Shin, Heeju (2008). "Unraveling the Economic Paradox of FemaleHeaded Households in Mexico: The Role of Family Networks." Sociological Quarterly 49(3): 565-595.

Winick, M., Meyer, K. K. and Harris, R. C. (1975). "Malnutrition and Environmental Enrichment by Early Adoption." Science 190(4220): 1173-1175. 
World Bank (2006). "Mexico's Competitiveness: Reaching Its Potential." Programmatic AAA Phase 2 Report No. 35388-MX. 